\title{
Article \\ Perceived Benefits of Energy Efficiency in the Spanish Residential Market and Their Relation to Sociodemographic and Living Conditions
}

\author{
Eva Crespo Sánchez ${ }^{1, *}$, Silvia Spairani Berrio ${ }^{2, *}$, Belén Onecha Perez ${ }^{1(\mathbb{C})}$ and Carlos Marmolejo-Duarte ${ }^{3(1)}$ \\ 1 Architecture Technology Department, Barcelona School of Architecture, Polytechnic University of Catalonia, \\ 08028 Barcelona, Spain; belen.onecha@upc.edu \\ 2 Architectural Constructions Department, Polytechnic School (EPSA), Alicante University, \\ 03690 San Vicente del Raspeig, Spain \\ 3 Centre for Land Policy and Valuations, Architecture Technology Department, \\ Barcelona School of Architecture, Polytechnic University of Catalonia, 08028 Barcelona, Spain; \\ carlos.marmolejo@upc.edu \\ * Correspondence: eva.crespo@upc.edu (E.C.S.); silvia.spairani@ua.es (S.S.B.); Tel.: +34-667-029-630 (E.C.S.); \\ +34-639-519-817 (S.S.B.)
}

check for updates

Citation: Crespo Sánchez, E.; Spairani Berrio, S.; Onecha Perez, B.; Marmolejo-Duarte, C. Perceived Benefits of Energy Efficiency in the Spanish Residential Market and Their Relation to Sociodemographic and Living Conditions. Appl. Sci. 2021, 11, 875. https://doi.org/10.3390/ app11020875

Received: 22 December 2020

Accepted: 15 January 2021

Published: 19 January 2021

Publisher's Note: MDPI stays neutral with regard to jurisdictional claims in published maps and institutional affiliations.

Copyright: (c) 2021 by the authors. Licensee MDPI, Basel, Switzerland. This article is an open access article distributed under the terms and conditions of the Creative Commons Attribution (CC BY) license (https:// creativecommons.org/licenses/by/ $4.0 /)$.
Featured Application: Tailoring of energy performance diffusion regarding public and private policies in countries where energy efficiency is not clearly seen as a source of benefits in the residential context.

Abstract: Within the Energy Performance of Buildings Directive information symmetry regarding financial and environmental benefits, coming from real estate performance, is a key element in the promotion of efficient buildings. However, the link between energy efficiency and its perceived co-benefits is far from perfect in EU countries with a short trajectory in the promotion of such residential attributes, endangering the efficacy of information-symmetry policies. Using a large survey applied to sellers, buyers, lessors and tenants this paper explores, in Spain, the perceived co-benefits in terms of energy savings and thermal comfort of efficient homes and whether such perception correlates to current living conditions, housing tenure and sociodemographic profile of respondents. Results suggest that in general such co-benefits are present in the mind of the main agents of the housing market. However, their perception is far from being homogeneous, it is clearer in the case of households whose current home is poorly insulated or inadequately serviced in terms of thermal active systems. Sociodemographic conditions also play a role in co-benefits perceptions: Elder, wealthier and landlords, irrespective of whether they act as sellers, buyers or lessors, do perceive to a larger extent the co-benefits of efficient homes. Such findings signal clear paths for the improvement of energy and housing policy.

Keywords: energy-performance; residential market; efficiency co-benefits; Spain

\section{Introduction}

The existing building stock in European countries accounts for over $40 \%$ of final energy consumption, of which residential use represents $63 \%$ of total energy consumption in the buildings industry [1]. As a result, the Energy Efficiency of Buildings Directive (EPBD, 2002/91/EC; 2010/31/UE; 2018/844/UE) and the Energy Efficiency Directive (2012/27/UE) necessitate the main communitarian policy to tackle emissions and energy expenditure in existing and new premises. Besides strict requirements for new and full retrofitted buildings, the directive is largely based on the information-symmetry hypothesis [2]. Such a rationale supports the idea that consumers prioritize efficient premises when they are informed of their financial and environmental benefits. Eventually, such a preference may increase their willingness to pay for efficient premises, in turn large prices may 
offset production over costs incentivizing developers to deliver new buildings with energy performance that surpasses the minimum required by construction codes or retrofitting inefficient buildings $[3,4]$. In summary, increasing information provided to consumers and producers on benefits when applying energy efficiency criteria to buildings can result in a virtuous cycle of production of efficient real estate.

In that framework, the EPBD designed the Energy Performance Certificates (EPC) aimed at providing prospective users with information regarding energy consumption and $\mathrm{CO}_{2}$ emissions as proxies for financial and environmental benefits. Past research [5,6], reviewed in Section 2, coming from countries such as Spain with relatively mild-winters and who are relatively new to the promotion of efficient buildings, illustrates the link between the performance of buildings and the benefits seems not to be fully established [5-7]. This flaw is especially present in countries where the residential market is dominated by homeowners, thus sellers, buyers and tenants are households, at the time that assessment coming from property agents does not place a special importance on energy efficiency in the marketing of homes $[8,9]$. Furthermore, it seems there is a misunderstanding on the role of EPCs and a generalized lack of awareness among potential home users, especially in the case of vulnerable populations at risk of fuel poverty. This latter risk is mainly concentrated in neighborhoods built before the first construction code imposing minimum insulation requirements were in place (NBE-CT-79, 1979) as well as regulations requiring minimum performance of heating devices (RD 1648/1980). Not surprisingly, according to the Spanish Ministry of Energy and Industry, by the end of 2018 only $1.1 \%$ of EPC certified existing buildings were rated as " $\mathrm{A}$ " or " $\mathrm{B}$ ". At the same time the number of energy efficiency retrofits were almost non-existent, despite the fact that the National Building Legislation (RD 38/1999) obligated that landlords must guarantee the conservation of their real estate, mainly at a functional, safety and habitability level, as well as the legislation on Retrofit, Regeneration and Urban Renewal (RD 8/2013). However, around 51\% of retrofits were the result of compulsory requirements of city councils so as to maintain the safety and major health implications coming from the poor conservation of buildings. Specifically, the more vulnerable areas are where less maintenance interventions are carried out, even with public financial support, usually due to the lack of collective agreements as a result of the community breakdown, and a poor perception on the potential co-benefits.

As a result, the lack of a strong link between perceived co-benefits and energy efficiency may menace the effectiveness of the EPBD policy in a national context where energy retrofits are strongly required.

This paper uses a large survey applied to households in Spain that have recently sold, bought or leased a home, as tenants or lessors in order to explore:

(1) Whether the link between energy efficient homes and their co-benefits in the form of energy savings and comfort is fully established among respondents

(2) Whether such co-benefits are contingent to the current living conditions expressed as priorities of home improvements including those related to energy-efficiency

(3) Whether such co-benefits are correlated with sociodemographic information of respondents and preferred tenure regime

In brief, this paper builds from the hypothesis that perceived co-benefits are related to individual features and influenced by current living conditions, where the housing tenure plays a role in how benefits are assessed.

The steps towards the verification of this hypothesis are the following: First, the review of barriers to energy performance diffusion, the role of perceived benefits and past research in this field in Spain; secondly, the description of the case study, data and research methods; thirdly, the explanation and discussion of results; and finally, the presentation of conclusions that summarizes the key findings which are placed in a broader perspective of public policy. 


\section{Barriers to Energy Performance Diffusion, The Role of Perceived Benefits and Past Research in Spain}

In order to better understand the present context, which is the departure point of this research, it is important to analyze which are the barriers that slow down the global diffusion of energy efficiency criteria, also which kind of benefits are perceived by users, to end with the particular situation in Spain.

\subsection{Barriers to Energy Performance Diffusion}

Despite the worldwide knowledge about the importance of reducing $\mathrm{CO} 2$ emissions and energy consumption in order to stop climate change, the adoption of energy efficiency criteria in buildings still finds multiple barriers. The EU Energy and Climate Commissioner in 2017, Miguel Arias Cañete, identified some of them as explained below [10]. Regarding the origins of the barriers it is possible to distinguish between:

- Economic barriers; as the lack of economic or tax incentives (which in Spain is worsened by the dispersal of local, regional and state regulations and jurisdictions), the incremental cost of the design and construction of a new building when it includes a comprehensive study on energy performance, the uncertainty of energy savings and the long payback periods.

- However, the barriers go beyond economic aspects since there are socio-cultural barriers embedded, such as the lack of public awareness or the change resistance of the construction industry.

- There are also technical barriers regarding the inadequate technical training; the projects dispersion and diversity or the scarce data about the projects' performance, not to mention the green-wash that is still used by many companies when mentioning just one building energy performance improvement, hiding or neglecting the relevance of other issues [11].

However, a large proportion of the causes for the slow dissemination of energy efficiency measures applied to the construction sector lies with individuals themselves. This conclusion was put forward by the study of Lambea, Grau y Pastor [12]. Such authors used a survey applied to 23 stakeholders in order to learn their motivations to implement sustainable criteria in property design and development. Their interviewees came from public and private building organizations including civil servants, developers, design firms and architecture schools. The results of such a study were interesting given that $70 \%$ of respondents recognized the need to have implemented sustainability criteria due to regulatory requirements, not because they have any personal interest resulting from belief on an objective. Only $17.6 \%$ said their actions were motivated because they perceived that final clients were interested in the benefits of energy performance. Such conclusions are compatible with the goal of the EPBD, as said before, to provide information symmetry regarding private (e.g., energy savings) and public benefits (e.g., environment conservation) of buildings' energy performance.

When referring to the benefits perception it is necessary to distinguish between energy consumption and energy demand, as explained by García et al. [13], "If energy savings and efficiency were just measured in terms of consumption, it might appear the paradox of talking about large savings when actually no previous consumption to be reduced did exist" (authors self-translation), which usually happens to people living under fuel poverty conditions. This suggests that when developing energy efficiency criteria in residential buildings passive solutions should be prioritized. It must be stressed this way to technicians and suppliers, against industry preferences based on consumption reductions through facilities renewal, a strategy that has the opposite effect, as was seminally argued by William Stanly Jevons in his book "The Coal Question" [14], demonstrating that when efficiency grows, immediate consumption decreases, but the use of the new efficient technology increases, which ends with a higher global consumption.

As a matter of fact, these barriers are nothing else but opportunities, among them: Specific technical training, new products and materials, jobs creation and new economic 
incentives, all of which must be well-directed according to the socio-economic field and living conditions of the residential target. However, the adoption of these new technologies largely relies on the perception of potential benefits as next discussed.

\subsection{The Role of Perceived Benefits}

Energy efficiency benefits can be divided into two groups: Macroeconomic ones (environmental, economic and social) and private ones (user level as building quality, economic and users' wellbeing) as shown in Figure 1. This section looks in particular at a small part of private co-benefits, mainly economic and wellbeing (thermal and environmental) as these aspects are more tangible for users in a first awareness phase, especially the advantages of energy efficiency improvements in residential context, but also seems to be the most influential in fostering the diffusion of efficient premises.

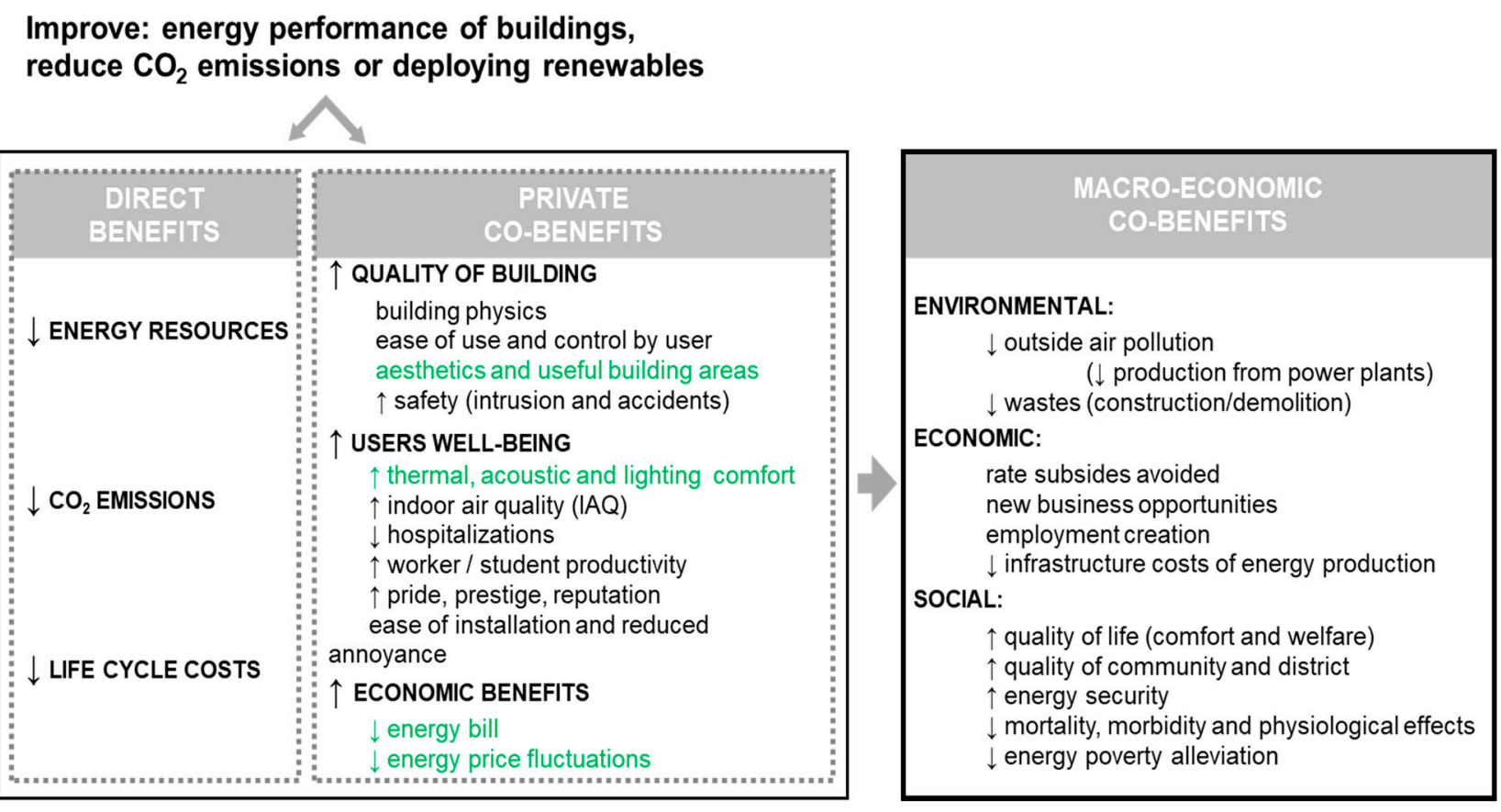

Figure 1. Energy performance's benefits and co-benefits classification. Source: Self elaboration from the study "Impact of co-benefits on the assessment of energy related building renovation with a nearly-zero energy target" [15].

Regarding private co-benefits studies, at a European level it can be noted some tendencies on co-benefits categories with higher representativeness on energy retrofits. Ferreira et al. [15] found that thermal transmittance improvement (i.e., reduction) is perceived as a way to improve thermal comfort and external noise, gain certainty on energy bills (since it is exposed to energy price fluctuations) as well as providing social pride and prestige. This latter "signalling effect" has also been pointed out by Fuerst et al. [16]. That evidence is in line with the work of Dempsey et al. [17] that stress the relevance of energy efficiency co-benefits especially in the case of low-income households. Accordingly, for that group these benefits positively affect community pride, improved access to local services and social cohesion [17].

Thus, private co-benefits are presented also in the form of sociological rewards for responsible consumption.

Previous research has also assessed the relevance of co-benefits. Table 1 contains a selection of studies aimed at quantifying direct benefits and co-benefits of thermal retrofits in three countries coming from the review of Ürge-Vorsatz et al. [18]. The cobenefits assessed in such a table include comfort, avoided $\mathrm{CO}_{2}$ and other non-Greenhouse Gases pollutants (e.g., of non-GHG: $\mathrm{SO}_{2}, \mathrm{NO}_{2}$ or $\mathrm{PM}$ ), reduction of hospital admissions, avoided excess winter mortality and morbidity, as well as reduction in days away from 
school and work. Clearly, as shown in Table 1, the ratio of benefits to costs (B/C) increases when considering co-benefits. In Ireland the ratio is 1.7 considering only net direct benefits such as energy-savings and it increases up to 2.0 when co-benefits are included; in New Zealand it increases from only 0.44 or 0.35 (depending on the discount rate) to 1.87 or 1.51; and in Hungary it increases from 0.9 to 2.6 (in a middle-intensity retrofit scenarioMID retrofit scenario) or 1.7 (in a deep retrofit scenario-DEEP scenario), suggesting that intensive retrofit scenarios are not necessarily the most profitable. Table 1 also provides the relative importance of co-benefits according to its net present value at the indicated discount rates. Interestingly, if only energy savings are taken into consideration, the paybacks are measured in decades, while if co-benefits were included, such time would be dramatically reduced. 
Table 1. Quantitative assessment of the importance of co-benefits for selected case studies.

\begin{tabular}{|c|c|c|c|c|c|c|c|c|c|}
\hline 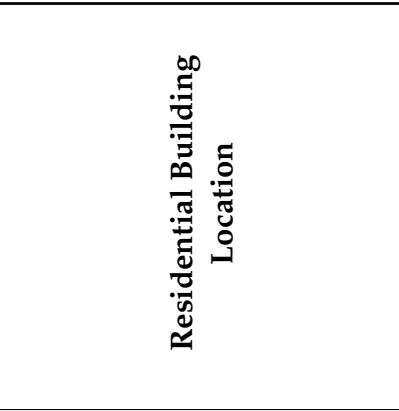 & 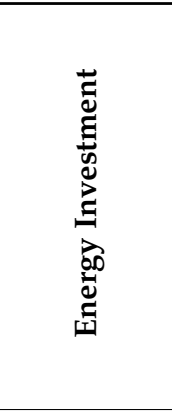 & 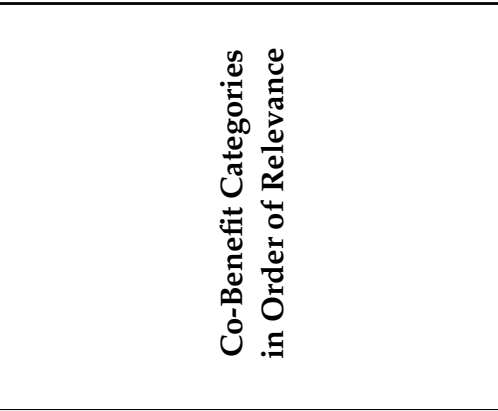 & 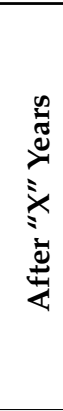 & 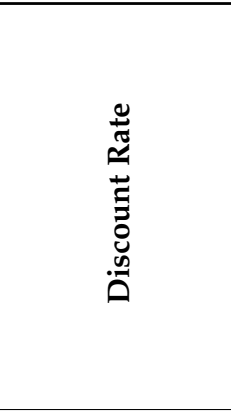 & 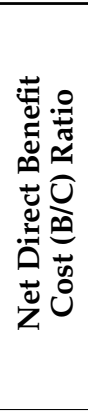 & 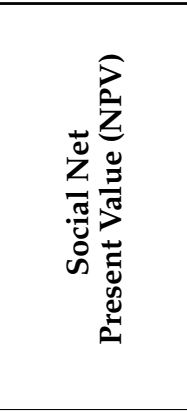 & 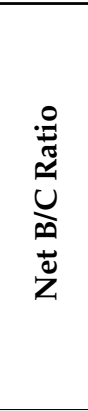 & 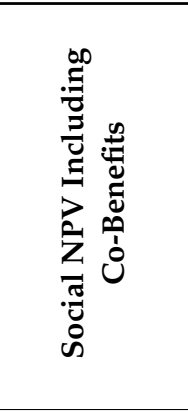 & 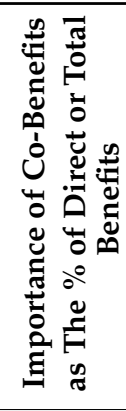 \\
\hline $\begin{array}{c}\text { Ireland } \\
\text { source: Clinch et al. [19] }\end{array}$ & $\begin{array}{l}\text { thermal } \\
\text { retrofit }\end{array}$ & Comfort & 31 & $5 \%$ & 1.7 & $1111 \mathrm{M} €$ & 2.0 & $3124 \mathrm{M} €$ & $75 \%$ \\
\hline \multirow{2}{*}{$\begin{array}{c}\text { Ireland } \\
\text { source: Clinch et al. [19] }\end{array}$} & \multirow{2}{*}{$\begin{array}{l}\text { thermal } \\
\text { retrofit }\end{array}$} & $\begin{array}{l}\text { Avoided emissions of } \mathrm{SO}_{\mathrm{X}}, \mathrm{NO}_{\mathrm{X}} \\
\mathrm{PM}_{10} \text { and } \mathrm{CO}_{2}\end{array}$ & \multirow[t]{2}{*}{31} & \multirow[t]{2}{*}{$5 \%$} & \multirow[t]{2}{*}{1.7} & \multirow[t]{2}{*}{$1111 \mathrm{M} €$} & \multirow[t]{2}{*}{2.0} & \multirow[t]{2}{*}{$3124 \mathrm{M} €$} & \multirow[t]{2}{*}{$75 \%$} \\
\hline & & $\begin{array}{c}\text { Avoided excess winter } \\
\text { mortality and morbidity caused by } \\
\text { energy poverty }\end{array}$ & & & & & & & \\
\hline $\begin{array}{c}\text { New Zealand } \\
\text { source: Chapman et al. [20] }\end{array}$ & $\begin{array}{l}\text { thermal } \\
\text { insulation }\end{array}$ & Reduced hospital admissions & 30 & $\begin{array}{l}5 \% \\
7 \%\end{array}$ & $\begin{array}{l}0.44 \\
0.35\end{array}$ & $\begin{array}{c}786 \\
\text { NZ\$/house } \\
635 \\
\text { NZ\$/house }\end{array}$ & $\begin{array}{l}1.87 \\
1.51\end{array}$ & $\begin{array}{c}3373 \\
\text { NZ\$/house } \\
2725 \\
\text { NZ\$/house }\end{array}$ & $329 \%$ \\
\hline \multirow{3}{*}{$\begin{array}{c}\text { New Zealand } \\
\text { source: Chapman et al. [20] }\end{array}$} & \multirow{3}{*}{$\begin{array}{l}\text { Thermal } \\
\text { insulation }\end{array}$} & Reduced days away from school & \multirow{3}{*}{30} & \multirow{3}{*}{$\begin{array}{l}5 \% \\
7 \%\end{array}$} & \multirow{3}{*}{$\begin{array}{l}0.44 \\
0.35\end{array}$} & \multirow{3}{*}{$\begin{array}{c}786 \\
\text { NZ\$/house } \\
635 \\
\text { NZ\$/house }\end{array}$} & \multirow{3}{*}{$\begin{array}{l}1.87 \\
1.51\end{array}$} & 3373 & \multirow{3}{*}{$329 \%$} \\
\hline & & Reduced days off work & & & & & & & \\
\hline & & Avoided emissions of $\mathrm{CO}_{2}$ & & & & & & NZ\$/house & \\
\hline $\begin{array}{c}\text { Hungary } \\
\text { source: Tirado et al. [21] }\end{array}$ & $\begin{array}{l}\text { thermal } \\
\text { retrofit }\end{array}$ & $\begin{array}{l}\text { Avoided emissions of } \mathrm{SO}_{X}, \mathrm{NO}_{X} \\
\mathrm{PM}, \mathrm{NMVOC} \text {, heavy metals, } \mathrm{CO}_{2} \\
\text { etc. }\end{array}$ & 40 & $\begin{array}{c}5.5 \% \text { MID } \\
\text { scenario DEEP } \\
\text { scenario }\end{array}$ & $\begin{array}{l}0.9 \\
0.9\end{array}$ & $\begin{array}{l}320 \mathrm{M} € \\
3125 \mathrm{M} €\end{array}$ & $\begin{array}{l}2.6 \\
1.7\end{array}$ & $\begin{array}{c}7453 \mathrm{M} € \\
11,134 \mathrm{M} €\end{array}$ & $\begin{array}{r}97 \% \\
174 \%\end{array}$ \\
\hline \multirow[b]{2}{*}{$\begin{array}{c}\text { Hungary } \\
\text { source: Tirado et al. [21] }\end{array}$} & \multirow{2}{*}{$\begin{array}{c}\text { thermal } \\
\text { retrofit }\end{array}$} & Comfort & \multirow{2}{*}{40} & \multirow{2}{*}{$\begin{array}{l}5.5 \% \text { MID } \\
\text { scenario DEEP } \\
\text { scenario }\end{array}$} & \multirow{2}{*}{$\begin{array}{l}0.9 \\
0.9\end{array}$} & \multirow{2}{*}{$\begin{array}{l}320 \mathrm{M} € \\
3125 \mathrm{M} €\end{array}$} & 2.6 & \multirow{2}{*}{$\begin{array}{c}\text { 7453 M€ } \\
11,134 \mathrm{M} €\end{array}$} & \multirow{2}{*}{$\begin{array}{c}97 \% \\
174 \%\end{array}$} \\
\hline & & $\begin{array}{l}\text { Avoided excess winter } \\
\text { mortality caused by } \\
\text { energy poverty }\end{array}$ & & & & & 1.7 & & \\
\hline
\end{tabular}


Regarding health co-benefits Ugarte et al. [22] stress the relevance of some of them which especially affect the low-income households:

- Indoor average temperatures: As example, the indoor temperatures should be maintained above $18{ }^{\circ} \mathrm{C}$, otherwise the prolonged exposure to lower temperatures may cause physical unrest and even mental diseases [23,24].

- Humidity: As example, Fraunhofer IBP (2016) estimates that 2.2 million Europeans have asthma as a direct result of living in damp or moldy buildings [25].

- Indoor air quality: The survey carried by Universitat de Barcelona-Hospital Clínic (Interstitial Diffuse Lung Disease Programme), shows thorough quantitative and qualitative evidence of the relationship between lung diseases and microorganisms present in air indoors. China provides another case where indoor air pollution is estimated to cause some 1.6 million premature deaths per year [26].

The main conclusion to be drawn from the aforementioned studies is that it is necessary to continue working on studies reporting to users and quantifying their perceptions and concerns in order to understand the co-benefits from the energy performance improvements beyond the environmental impact. It will also be a crucial matter to emphasize the social and economic aspect that can promote on a massive scale these improvements. In that vein, the work of Lavelle and Fahy [27] explores the environmental attitude of buildings' users by means of a survey within the Consensus Lifestyle Survey. These authors find divergent approaches: (1) proactive attitudes showing awareness on environmental emergency and the necessity to act on a small-scale level in order to achieve a global impact " $\mathrm{I}$ ' $\mathrm{m}$ willing to sacrifice some comfort to save energy" or "It's important to use less energy and lower utility use"; (2) passive attitudes which shows a degree of environmental awareness but as a third party "Society needs to consume less to protect environment for future generations"; and (3) attitudes which are against energy concessions considering them as an obstacle for their life quality and possession of goods "My quality of life will be reduced by decreasing energy use or it takes too much of my time to reduce energy use".

Whether co-benefits are correctly perceived by buildings' users before and after energy retrofits has also been researched. The city council of Santa Coloma de Gramanet (Spain), in the province of Barcelona, implemented a large-scale energy retrofit in a low-income neighborhood, using powers derived from urban law. In this project the city council funded the cost of the retrofit and recovered the investment by means of payments charged to landlords across five years. The improvement consisted of improving insulation both in external walls and roofs of multifamily homes. Surveying residents, Barón et al. [28] tried to explore the perceived co-benefits of such large retrofit. According to their results $62 \%$ of respondents had noticed a better indoor temperature as a consequence of higher surface temperature on the walls and less energy exchange through the façades, and also a higher building quality at three levels: Home ( $30 \%$ of respondents believe their home had raised its market value); building ( $10 \%$ of respondents consider that neighbor's relationship had improved); and neighborhood ( $16 \%$ considering a better social environment and $45 \%$ believing the area had been dignified). In the same vein, Ahrentzen et al. [29] using an instrument-based approach, researched the measurable improvements in the context of the Energy Efficiency Retrofit Action of Homes of Older Adults in Phoenix (the US). The measurements performed showed that energy consumption fell 19\% after the energy retrofit, at the same time there was a reduction of interior extreme temperatures. Such improved conditions are compatible with the reported improvement of occupants' health. Despite these positive indicators, this study failed to identify any improvement on users' perceptions. This finding suggests that demographics may play a role in co-benefits perceptions. Stephenson et al. [30] arrived at divergent conclusions (see Figure 2). Their study was focused on the context of a retrofit implemented in 20 homes in Ireland and it was based on surveys to users regarding the perceived co-benefits. The main differences between the pre-retrofit status and post-retrofit status regarding thermal comfort was that at the beginning $50 \%$ of respondents were very dissatisfied, but this percentage dropped to $21 \%$ in the post-retrofit situation. When considering the energy bills, respondents' 
satisfaction grew from $40 \%$ at the beginning to $74 \%$ after the intervention. Finally, the financial incentives became a low priority at the time that lower utility bills became the larger incentive reaching $48 \%$. Interestingly the energy label was not considered as a relevant element before nor after implementing the retrofit. Furthermore, it seems that the co-benefits associated to environment conservation are absent as well, both before and after the performance improvement.

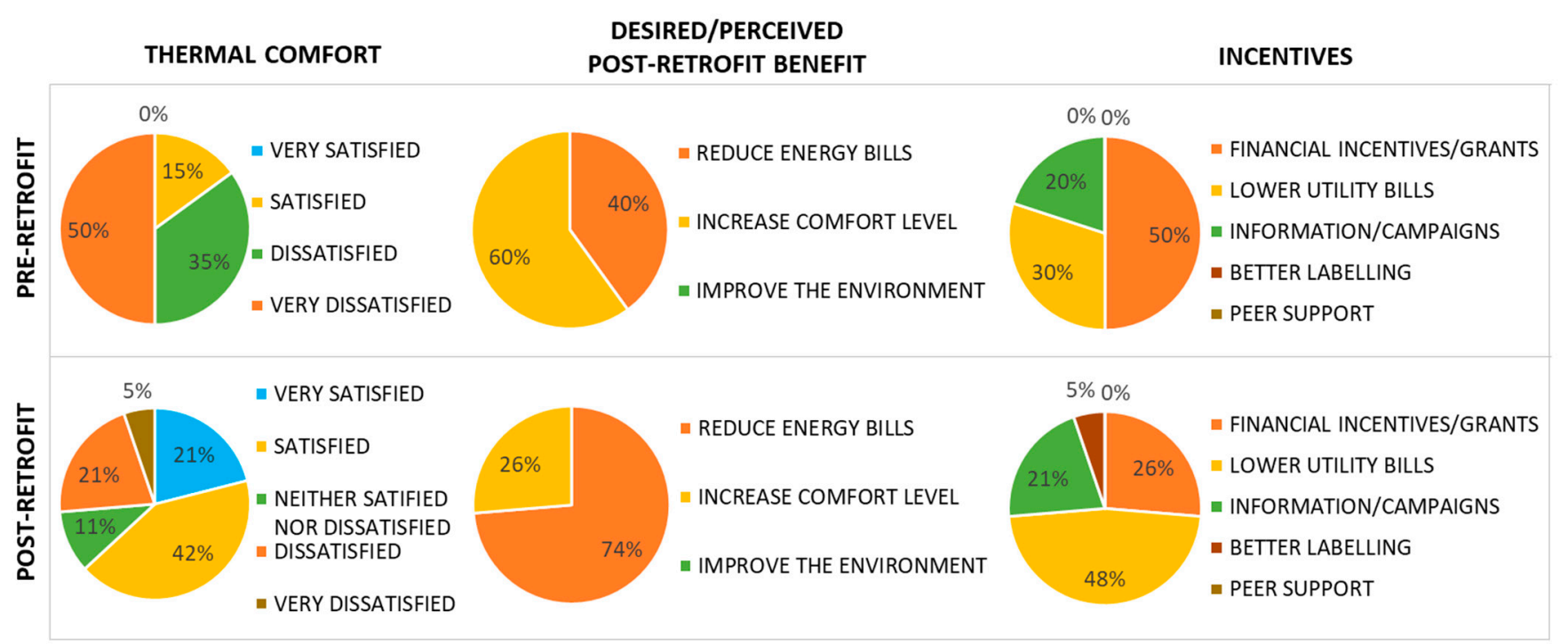

Figure 2. Perceived co-benefits or energy performance before and after the retrofit program. Source: Own elaboration using Stephenson et al. [30] data.

Finally, it is worth taking into consideration the study of Pelenur [31] implemented in Manchester and Cardiff (UK) using the Q methodology. Such a study identifies the existence of two different groups of users, the first one with a proactive perspective of energy efficiency (reducing consumption or even demand requirements), while the second one had a reactive perspective (compensate consumption through the use of renewable energies). The most relevant aspect of this analysis is that environmental awareness of users is not enough reason to foster the energy efficiency improvement interventions in buildings, especially if these require a high initial investment.

Overall, it seems that the correct perception of energy performance benefits is not enough to foster energy retrofits; at the same time that demographics, cultural and socioeconomics may play a role in shaping such perceptions.

\subsection{Past Research in Spain}

In Spain, the effect of energy performance over the dynamics of the residential market has been researched from the perspective of revealed and stated preferences. In the first body of work, the research of Marmolejo [32] based on a hedonic price analysis for Barcelona uncovered a small but positive correlation between EPC ratings and listing prices. Similarly, other works have identified specific hedonic agendas across the country and time: Marmolejo and Chen [33] indicated the effect is larger in cities where efficient homes are scarce, while Marmolejo and Chen [4] concluded that within the same city it is larger in the low-quality home tier, while being null in the case of high efficient state-of-the-art ones, suggesting a misunderstood role of such ratings since they are probably understood as general quality indicators. Taltavull et al. [34] found, also, a small effect on home prices when controlling for an extensive location and architectural attributes in Alicante. As well as Céspedes-López et al. [35] who report that owners have no incentives to disclose EPC ratings at property advertisements allowing them to sell low-tier EPC homes at the price of up-tier ones. While the best rated homes (i.e., " $\mathrm{A}$ " " $\mathrm{B}$ ") exhibit prices comparable to those rated as less efficient. 
Interestingly, the aforementioned misperception of the role of EPC ratings is not exclusive to households. Marmolejo et al. [8] surveyed a sample of real estate agents across the country to learn the awareness level on EPCs and the effect that EPC ratings have on home marketing. They found that some of such property professionals do also misunderstand the role of the EPCs, since they are perceived as general indicators of home quality or comfort instead of what they are; that is, indicators of energy consumption (to reach a standard comfort level) and $\mathrm{CO}_{2}$ emissions. They also found that, in the opinion of realtors, energy performance is not a key element in home pricing, speed to market nor price negotiation. Which is in line with the small, and possible incorrectly, marginal price found in hedonic price studies.

From the stated preferences techniques Marmolejo, García-Hooghuis and GarcíaMasià [5] used a contingent valuation to learn whether households are willing to make an extra payment for top-efficient homes in Barcelona. Their conclusions suggest that people are willing to pay a similar quantity to the indicated monthly energy savings, coming from improved energy-performance conditions. They found that personal respondents' attributes such as income, environmental awareness, awareness of the EPC scheme or the fact that the use of efficient homes can be seen as a socially responsible behavior do increase the aforesaid extra payment. Interestingly, the perceived co-benefits such as energy savings as well as the living conditions were also correlated with prices: The worse the living conditions, the larger the willingness to pay (WTP) for efficient homes. Moreover, respondents willing to buy the offered home (instead of leasing it) said they were ready to pay more. In a further work, Marmolejo, García-Hooghuis and García Masià [6] using a larger and more recent sample, in the context of a contingent valuation, also in Barcelona, were able to segment it in order to identify sociodemographic specific reasons to be ready to make an extra payment for efficient homes. Their results suggest that young respondents whose education is in progress, seem to have developed an environmental concern that renders a larger WTP when they come from affluent families, although such payment is lower in the case of women, especially in the case of young women. The second interesting conclusion of such a work indicates that young adults that have failed to emancipate are less prepared to pay for such attributes, since they are not fully aware of the family budget impact of energy bills or simply because they are not in financial conditions to establish an independent household. Additionally, perceived co-benefits such as health and comfort were found to be positively influencing the respondents' WTP. Altogether, these works suggest that WTP is largely influenced by perceived co-benefits such as energy savings, improved health and comfort as well as other co-factors such as living conditions, environmental sensibilities, income and demographic features.

Marmolejo et al. [5,6] also reported a large unawareness of the EPC scheme in the country, especially in the case of the poor educated and less affluent population. The same conclusion is true regarding the technical units in which energy efficiency benefits and co-benefits are expressed in EPC labels. In summary, people at risk of fuel poverty who could benefit the most from learning about and understanding the impact of efficiency of their prospective homes, are the most uninformed or ready to understand the financial and environmental implications of energy performance. In fact, such unawareness is reflected in the presented regression models: The larger the unawareness or misunderstanding of the EPC scheme the smaller the WTP for efficient homes.

Finally, Marmolejo, García-Hooghuis and Spairani [36] in-depth interviewing of key stakeholders of the housing market tried to uncover whether energy performance is a priority when delivering their design, construction, financial or property development and valuation services. Their findings suggest that such a home attribute is, in general, not a priority since they found that households do not place special interest on top-efficient premises. However, they indicated that there is a small market segment willing to engage with sustainable homes. Such an exception is made of well educated, young, and affluent households that also have developed environment conservation awareness and behavior. These findings are in line with the work of Lambea, Grau y Pastor [12]. 
In summary, in Spain, the vicious cycle of inaction suggested by Cadman [37] two decades ago seems to be established. More research is needed to understand why households, in general, do not seek to buy or lease efficient homes. Understanding the perceived co-benefits of energy efficiency and the correlation of such perception with present living conditions and socioeconomic attributes is a key element in filling such a gap as it is done in this paper.

\section{Case Study, Materials and Methods}

In this paper households' perceptions on energy benefits, living conditions and sociodemographic features are gathered using a questionnaire integrated into the Fotocasa Research Annual Survey. The survey was implemented using a panel of households complemented by actual home seekers coming from Fotocasa property listings that ranks among the largest in the country. The sample was representative in sociodemographic terms of the Spanish population participating in the selling and leasing housing markets in the country. It was applied to people between 18 to 75 years old, rendering a sample error of $\pm 1.4 \%$, using an online platform in the first quarter of 2020 (before the National State of Alarm was declared due to the COVID-19 pandemic). After selecting owners that have sold, bought or leased a home as well as tenants that have leased their current home in the last year, the sample analyzed in this paper was made of 6167 households.

Using a 1 to 10 linear scale respondents were required to express their agreement level with some affirmations regarding co-benefits associated with energy efficiency, such as: Savings in the electricity and gas bills, improvement of interior comfort and regulation of internal temperature. Deliberately, aspects such as comfort were stated in a broad form so as to allow the introduction of aspects such as air infiltrations, soundproof issues or condensations (largely present in Spanish homes due to improper envelope insulation and lack of correct ventilation [38] as discussed in 2.2). In the same way, respondents were required to respond whether they consider that energy-efficient homes render a larger market price so as to indirectly learn whether they are willing to bid a larger amount for such kind of efficient premises. Furthermore, respondents were asked to respond whether their present home does require specific retrofits in three dimensions: (1) non-energy efficiency retrofits, (2) energy efficiency passive measures and (3) energy efficiency active measures. Non-energy efficiency measures include aspects related to aesthetics, functional and accessibility improvements of homes in kitchens, bathrooms and layouts. It is worth saying that despite any home transformation has energy performance implications, the usual changes introduced in the assessed retrofits largely rely on aesthetics, functionality and accessibility. Energy passive retrofits splits into window and wall insulation and improvement or setting up of sun/wind protections in the form of awnings and foldable window blinds largely present in traditional architecture in Mediterranean homes. It is worth saying that window and wall insulation improvement in Spain is also perceived as a way to deliver larger soundproof standards, in a country where multifamily homes are dominant (implying noise issues coming from other homes and common areas) and compact, diverse and vibrant urban fabrics produce external noise pollution [39]. Energy efficiency measures regarding active systems split into improvement in Heat Ventilation Air Conditioning (HVAC) systems as well as domestic hot water. Thus, actions such as installing or upgrading present systems (e.g., boilers or heat pumps) to reach higher levels of energy efficiency were inquired. Finally, information such as sex, age, net family income level, civil status, zip code, present home tenure and province of residence were inquired. Academic attainment was not researched since in past Adevinta studies its relationship with property preferences was weaker in relation to income level. Information gathered from the survey has been complemented with:

(1) Population of the municipality where respondents live (Padrón de Población, INE, 2019). This information allows to identify any difference coming from the size of property markets and cultural influences (e.g., environmental awareness) coming from urban environments; and whether such co-benefits are contingent to the current 
living conditions expressed as priorities of home improvements including these related to energy-efficiency.

(2) Household and personal income level (Income Tax Registry, INE, 2016) at census tract level. This information allows us to identify any bias provided by the self-declared household income level in the survey.

(3) Heating and Cooling Index (EHI and ECI) of the municipality where the respondent lives (European Hot and Cool Market from Euroheat.org). This information intends to control opinion differences coming from climatic divergences in the country. The $\mathrm{EHI}$ and ECI are normalized indexes $(100=$ average European condition $)$ from the degree days for heating and cooling. "Heating degree days" is a measure of how much (in degrees), and for how long (in days), outside air temperature was lower than a specific "base temperature" (see details in Ecoheatcool [40,41]). It is used for calculations relating to the energy consumption required to heat buildings. "Cooling degree days" is a measure of how much (in degrees), and for how long (in days), outside air temperature was higher than a specific base temperature. The measure of "heating degree days" expresses the heat requirement for a specific period of time considering environmental and interior temperature providing a proper comfort level, the same is done for the "cooling degree days". The larger the EHI and ECI indexes, the more the necessity to provide residential environments with heating and cooling.

Statistical descriptive analyses are used to identify perceived co-benefits of energy efficiency and present living conditions. In order to identify whether such benefits and conditions are different regarding specific market segments and sociodemographic conditions chi-squared tests as well as ANOVA tests were used depending upon the scale of the analyzed variable. Finally, in order to learn what factors do contribute to increase the perception of co-benefits associated to energy efficiency a regression model was implemented. Such a model is based in the following functional form:

$$
L n C B_{r}=\sum_{i}^{n} L c+\sum_{j}^{n} S c+\sum_{z}^{n} C
$$

where $L n C B$ is the natural $\log$ of a composite indicator of the perceived co-benefits $C B$ of a given respondent $r$ associated to energy efficiency. $L c$ is a vector formed of living conditions measured as priorities to implement specific retroefits in the respondent's present home associated to the three dimensions discussed before. $S c$ is the sociodemographic profile of the respondent. $C$ is a control vector associated to the environment where the respondent lives regarding heating, cooling indexes as well as the regional/urban location. Adevinta identifies nine regions along the country; such regions have been used as fixed effect controls in the model. Additionally, such regions have been used to build interaction variables to control divergences related to the relative importance of some of the retrofits (e.g., in continental climate zones air conditioning is not as relevant as efficient boilers and sun protection is less relevant than in Mediterranean regions). The logarithmic expression of the $C B$ allows to approach a normal distribution and, therefore, use the ordinary least squared method in the regression.

The $C B$ indicator is the principal component of a factor analysis made of the stated perceived level of co-benefits associated to: Energy savings, comfort and thermal interior regulation. Such a procedure eliminates any information redundancy and captures $71.12 \%$ of the variance of the original variables.

Finally, in order to eliminate outliers first, extreme values on the dependent variables have been eliminated; secondly following Marmolejo and González [39] the Mahalanobis distance has been used. This latter approach allows to identify the cases which independent attributes effectively correlated to the dependent variable are placed far from the general case distribution, and thus, bias the regression coefficients. 
According to Figure 3 respondents main age was the 35-54 years old cohort, which matches the age where people form stable households in the country, the average age was 41 years old, $61 \%$ were couples (married or not) and the most dominant net income range was less than 1603 euro/household/month. Further, 55\% of respondents came from the selling market, being $42 \%$ buyers. The remainder, $45 \%$, was made up of lessors and tenants. Therefore, the sample was predominantly made of consumers $(78 \%)$, that were households that have recently bought or leased a home as tenants. Regarding respondents' living place, $25 \%$ of them lived in the two largest cities (Madrid and Barcelona), while the remainder were distributed in a similar way to how principal homes are located across Spanish regions. Both the ECI and EHI exhibit significant variations across the sample which is coherent with the climatic divergences across the Iberian Peninsula and the Spanish Islands where both Mediterranean and cold continental climates are present. However, the average of the ECI was larger than 100 implying a larger requirement of cooling in relation to the European mean. The inverse condition is true for the EHI showing mild Spanish winters in relation to northern European countries.

n Min Max Average Std Dev Note

\begin{tabular}{|c|c|c|c|c|c|c|}
\hline \multicolumn{7}{|c|}{ Perceptions on the benefits of energy efficient homes ( $0=$ non benefits, $10=$ largest benefits) } \\
\hline Reduces electricity bill & 5,816 & 0 & 10 & 7.6 & 2.4 & $\mathrm{a}$ \\
\hline Reduces gas bill & 5,681 & 0 & 10 & 7.5 & 2.4 & $\mathrm{a}$ \\
\hline Increases comfort & 5,826 & 0 & 10 & 7.6 & 2.2 & $\mathrm{a}$ \\
\hline Aids preserving temperature & 5,881 & 0 & 10 & 8.0 & 2.0 & $\mathrm{a}$ \\
\hline \multicolumn{7}{|c|}{ Indirect inquiry on willingness to pay for energy efficient homes $(0=$ completely disagree, } \\
\hline A high efficient home is more expensive & 5,705 & 0 & 10 & 6.49 & 2.66 & $\mathrm{a}$ \\
\hline \multicolumn{7}{|c|}{$\%$ of respondents' present homes not requiring specific retrofits } \\
\hline Kitchen & 6,167 & 0 & 1 & $12 \%$ & $32 \%$ & \\
\hline Bath & 6,167 & 0 & 1 & $11 \%$ & $31 \%$ & \\
\hline Layout improvement & 6,167 & 0 & 1 & $13 \%$ & $33 \%$ & \\
\hline Wall insulation & 6,167 & 0 & 1 & $10 \%$ & $30 \%$ & \\
\hline Window insulation & 6,167 & 0 & 1 & $10 \%$ & $29 \%$ & \\
\hline Boiler energy-efficiency improvement & 6,167 & 0 & 1 & $14 \%$ & $35 \%$ & \\
\hline Install/improve energy efficiency AC & 6,167 & 0 & 1 & $13 \%$ & $34 \%$ & \\
\hline Install/improve solar protection & 6,167 & 0 & 1 & $11 \%$ & $32 \%$ & \\
\hline \multicolumn{7}{|c|}{ Priority to implement specific retrofits ithe current home of respondets $(0=$ no prioritary, $10=$ highest } \\
\hline Kitchen & 5,451 & 0 & 10 & 6.7 & 2.7 & $\mathrm{c}$ \\
\hline Bath & 5,485 & 0 & 10 & 6.5 & 2.8 & $\mathrm{c}$ \\
\hline Layout improvement & 5,389 & 0 & 10 & 4.7 & 2.8 & $\mathrm{c}$ \\
\hline Wall insulation & 5,566 & 0 & 10 & 6.8 & 2.7 & c \\
\hline Window insulation & 5,576 & 0 & 10 & 7.5 & 2.6 & $\mathrm{c}$ \\
\hline Boiler energy-efficiency improvement & 5,312 & 0 & 10 & 6.5 & 2.9 & $\mathrm{c}$ \\
\hline Install/improve energy efficiency AC & 5,344 & 0 & 10 & 5.6 & 3.0 & $\mathrm{c}$ \\
\hline Install/improve solar protection & 5,466 & 0 & 10 & 5.5 & 2.8 & c \\
\hline \multicolumn{7}{|c|}{ Climatic conditions and location of respondents' home } \\
\hline European Cooling Index (ECI) & 5,998 & 72 & 143 & 122 & 20.28 & $\mathrm{~d}$ \\
\hline European Heating Index (EHI) & 5,998 & 54 & 81 & 72 & 7.80 & $\mathrm{~d}$ \\
\hline Northeast and Balearic Islands & 6,167 & 0 & 1 & $9 \%$ & $29 \%$ & \\
\hline East & 6,167 & 0 & 1 & $10 \%$ & $31 \%$ & \\
\hline South & 6,167 & 0 & 1 & $14 \%$ & $35 \%$ & \\
\hline Centre & 6,167 & 0 & 1 & $8 \%$ & $27 \%$ & \\
\hline Northwest & 6,167 & 0 & 1 & $7 \%$ & $25 \%$ & \\
\hline North central & 6,167 & 0 & 1 & $7 \%$ & $25 \%$ & \\
\hline Canary Islands & 6,167 & 0 & 1 & $2 \%$ & $13 \%$ & \\
\hline Barcelona & 6,167 & 0 & 1 & $9 \%$ & $28 \%$ & \\
\hline Madrid & 6,167 & 0 & 1 & $16 \%$ & $36 \%$ & \\
\hline Oher zones & 6,167 & 0 & 1 & $18 \%$ & $39 \%$ & \\
\hline Province capital & 6,167 & 0 & 1 & $37 \%$ & $48 \%$ & $\mathrm{e}$ \\
\hline No province capital $<50.000$ inhabitants & 6,167 & 0 & 1 & $29 \%$ & $45 \%$ & $\mathrm{e}$ \\
\hline No province capital $>50.000$ inhabitants & 6,167 & 0 & 1 & $16 \%$ & $36 \%$ & $\mathrm{e}$ \\
\hline Non identified & 6,167 & 0 & 1 & $18 \%$ & $39 \%$ & $\mathrm{e}$ \\
\hline
\end{tabular}

\begin{tabular}{|c|c|c|c|c|c|c|}
\hline & $\mathbf{n}$ & Min & Max & Average & Std Dev & Note \\
\hline \multicolumn{7}{|c|}{ Respondents' sociodemographic features } \\
\hline$\overline{\text { Age }}$ & 6,167 & 18 & 75 & 41 & 12 & \\
\hline Age 18-24 & 6,167 & 0 & 1 & $7 \%$ & $26 \%$ & \\
\hline Age 25-34 & 6,167 & 0 & 1 & $29 \%$ & $45 \%$ & \\
\hline Age 35-54 & 6,167 & 0 & 1 & $49 \%$ & $50 \%$ & \\
\hline Age $>54$ & 6,167 & 0 & 1 & $15 \%$ & $36 \%$ & \\
\hline Socioeconomic ladder & 6,167 & 1 & 7 & 3.26 & 1.48 & f \\
\hline Income $>3004 €$ & 6,167 & 0 & 1 & $10 \%$ & $30 \%$ & $\mathrm{~g}$ \\
\hline Income $2452-3005 €$ & 6,167 & 0 & 1 & $28 \%$ & $45 \%$ & $\mathrm{~g}$ \\
\hline Income $1603-2145 €$ & 6,167 & 0 & 1 & $19 \%$ & $39 \%$ & $\mathrm{~g}$ \\
\hline Income $<1603 €$ & 6,167 & 0 & 1 & $44 \%$ & $50 \%$ & $\mathrm{~g}$ \\
\hline Women & 6,167 & 0 & 1 & $60 \%$ & $49 \%$ & \\
\hline Single & 6,167 & 0 & 1 & $29 \%$ & $45 \%$ & \\
\hline Married or partner & 6,167 & 0 & 1 & $61 \%$ & $49 \%$ & \\
\hline Divorced & 6,167 & 0 & 1 & $9 \%$ & $28 \%$ & \\
\hline Widow & 6,167 & 0 & 1 & $1 \%$ & $11 \%$ & \\
\hline Own their home & 6,167 & 0 & 1 & $56 \%$ & $50 \%$ & \\
\hline \multicolumn{7}{|c|}{ Respondents' relationship with the home property market } \\
\hline Buyer & 6,167 & 0 & 1 & $42 \%$ & $49 \%$ & \\
\hline Seller & 6,167 & 0 & 1 & $13 \%$ & $34 \%$ & \\
\hline Landlord (lesser) & 6,167 & 0 & 1 & $9 \%$ & $28 \%$ & \\
\hline Tenant & 6,167 & 0 & 1 & $36 \%$ & $48 \%$ & \\
\hline
\end{tabular}

Notes

$\mathrm{a}=$ Do not known and non responses were eliminated

$c=$ just considering the cases where respondents indicated these retrofits are required $\mathrm{d}=$ see definition in the main text

$\mathrm{e}=$ Province capitals exhibit specific property dinamics regardless the population $\mathrm{f}=$ this indicator is an ordinal scale according the income level, the larger the indicator, the lowert the net family income. It is made using the income ranges identified by the Spanish Association of Market Research which maximizes differences in consumers preferences

$\mathrm{g}=$ Net household monthly income

Figure 3. Descriptive statistics. Source: Self elaboration.

On a 1 to 10 scale, respondents' perception on co-benefits associated to energy-efficient homes averages 7.69, being the preservation of interior temperature the most relevant. Only $12 \%$ of respondents said their current home does not require any of the inquired 
retrofits associated to energy-efficiency and non-energy efficiency aspects. Such a figure is coherent with the poor living conditions provided by the Spanish market of existing homes. Moreover, $55 \%$ of the existing buildings in 2010 were constructed before 1980 when the first energy performance requirements were introduced by the building legislation (NBE-CT-79, RD 2429/1979). While most of them were designed before the present construction code (CTE 2006, RD 314/2006) requiring strict energy performance criteria were in place [42]. According to data coming from Energy Performance Certificates issued until 2018, only 5\% of the existing building stock lies in an A-to-C EPC rating (IDAE, 2018). From the $88 \%$ of homes requiring a retrofit, respondents said, on a 1 to 10 linear scale, the average priority is 6.23 .

\section{Results and Discussion}

\subsection{Perceived Co-Benefits From Efficient Homes}

According to Figure 4 the inquired co-benefits of efficient homes are clearer in the selling market in relation to the leasing one. As a matter of fact, each of the financial savings (i.e., electricity and gas) and comfort attributes are statistically higher in the selling market. The same trend is present in the indirect indicator of willingness to pay: Respondents belonging to the selling segment do think efficient homes are more valuable in relation to respondents belonging to the leasing segment. When data is split into buyers and owners (that have sold a home) for the selling market; and tenants and owners (that have leased) a home, interesting conclusions emerge. While in the selling market there are only two statistically different perceptions (comfort and value), in the case of the leasing market the perceptions are largely different in all of the assessed aspects. In general owners (i.e., lessors) do clearly appreciate the co-benefits of energy efficiency in relation to tenants more. In general, owners (i.e., buyers, sellers or lessors) do place a larger relevance on such benefits in relation to tenants. This finding is in line with the evidence reported in the Santa Coloma de Gramanet retrofit program where, according to the city council [43], $32.5 \%$ of the retrofitted homes were vacant but their owners were interested in supporting the retrofit. Moreover, it is correlated with the fact that in Spain the leasing tenure is seen as a transitory path towards ownership. However, this finding challenges the current housing policies in the country which foster the tenancy as a long-term housing tenure.

\begin{tabular}{|c|c|c|c|c|c|c|c|c|c|c|}
\hline & \multicolumn{5}{|c|}{ Market segments } & \multicolumn{5}{|c|}{ Selling segment } \\
\hline & \multicolumn{2}{|l|}{ Selling } & \multicolumn{3}{|l|}{ Leasing } & \multicolumn{2}{|l|}{ Buyers } & \multicolumn{2}{|l|}{ Owners } & \multirow[b]{2}{*}{ Sig. Anova } \\
\hline & Average & St Dev & Average & St Dev & Sig. Anova & Average & St Dev & Average & St Dev & \\
\hline Reduces electricity bill & 7.7 & 2.3 & 7.4 & 2.4 & 0.00 & & 2.3 & & 2.4 & 0.29 \\
\hline Reduces gas bill & 7.6 & 2.3 & 7.3 & 2.4 & 0.00 & & 2.2 & & 2.4 & 0.70 \\
\hline Increases comfort & 7.6 & 2.1 & 7.4 & 2.2 & 0.00 & 7.6 & 2.1 & 7.8 & 2.2 & 0.03 \\
\hline Aids preserving temperature & 8.1 & 1.9 & 7.9 & 2.1 & 0.00 & 8.1 & 1.9 & 8.1 & 2.1 & 0.49 \\
\hline Is more expensive & 6.5 & 2.6 & 6.3 & 2.6 & 0.01 & 6.6 & 2.6 & 6.4 & 2.8 & 0.06 \\
\hline \multirow[t]{4}{*}{$\mathrm{n}$} & 2,939 & & 2,327 & & & 2,204 & & 735 & & \\
\hline & \multicolumn{4}{|c|}{ Leasing segment } & & & & & & \\
\hline & Tenants & & Owners & & & & & & & \\
\hline & Average & St Dev & Average & St Dev & Sig. Anova & & & & & \\
\hline Reduces electricity bill & 7.3 & 2.5 & 7.8 & 2.3 & 0.00 & & & & & \\
\hline Reduces gas bill & 7.2 & 2.4 & 7.9 & 2.2 & 0.00 & & & & & \\
\hline Increases comfort & 7.4 & 2.2 & 7.6 & 2.0 & 0.01 & & & & & \\
\hline Aids preserving temperature & 7.8 & 2.1 & 8.1 & 1.9 & 0.00 & & & & & \\
\hline Is more expensive & 6.3 & 2.6 & 6.4 & 2.6 & 0.40 & & & & & \\
\hline $\mathrm{n}$ & 1,833 & & 494 & & & & & & & \\
\hline
\end{tabular}

Figure 4. Perceived benefits according to market segments and offer/demand sides. Source: Self elaboration.

In order to learn whether energy-efficiency benefits are contingent to personal attributes of respondents the sample has been split into subgroups according to sociodemo- 
graphic profiles. It is worth recalling that conclusions extracted in such a segmentation are not robust with the interference among segment variables, that is, the uneven distribution of respondents among different segmentation variables (e.g., there is a correlation between oldest respondents and less affluent households).

According to Figure 5, in general older respondents do clearly perceive the inquired benefits, namely that related to interior comfort; conversely, while the indirect indicator of willingness to pay does also increase in the case of older respondents, its slope is lower in relation to the remainder of the benefits. Interestingly, it seems that men perceive higher benefits in relation to women in all of the assessed aspects except in comfort where there the difference fails to be statistically significant. There is also a positive correlation between the net disposable household income and the perceived inquired benefits, but in the indirect indicator of willingness to pay. Interestingly, the main differences are among the middle and low income-tier, suggesting that above the "middle income-class" the perception of energy-efficiency (EE) benefits remain stable. Such a trend is clearer in the financial implications associated to energy savings. It is worth recalling the relationship between household wealth and educational attainment and environmental awareness (not inquired in the survey). In Spain, past research, has pointed out a positive correlation among these three sociodemographic dimensions [6]. Thus, it is highly probable the more educated population correctly understand the co-benefits of efficient homes. e

\begin{tabular}{|c|c|c|c|c|c|c|c|c|c|}
\hline \multirow[b]{4}{*}{ Reduces electricity bill } & \multicolumn{9}{|l|}{ Age } \\
\hline & \multicolumn{2}{|c|}{$18-24$} & \multicolumn{2}{|c|}{$25-34$} & \multicolumn{2}{|c|}{$35-54$} & \multicolumn{2}{|c|}{55 and more } & \multirow[b]{2}{*}{ Sig. Anov } \\
\hline & Avg & StDev & Avg & St Dev & Avg & St Dev & Avg & St Dev & \\
\hline & 6.8 & 2.5 & 7.4 & 2.3 & 7.7 & 2.4 & 7.9 & 2.3 & 0.00 \\
\hline Reduces gas bill & 6.7 & 2.4 & 7.3 & 2.2 & 7.6 & 2.4 & 7.8 & 2.3 & 0.00 \\
\hline Increases comfort & 6.8 & 2.3 & 7.2 & 2.1 & 7.6 & 2.2 & 8.1 & 2.0 & 0.00 \\
\hline Aids preserving temperature & 7.3 & 2.1 & 7.7 & 2.0 & 8.1 & 2.0 & 8.4 & 1.8 & 0.00 \\
\hline Is more expensive & 5.9 & 2.6 & 6.5 & 2.4 & 6.5 & 2.7 & 6.3 & 2.8 & 0.00 \\
\hline $\bar{n}$ & 353 & & 1,486 & & 2,610 & & 817 & & \\
\hline
\end{tabular}

Household net monthly income

\begin{tabular}{|c|c|c|c|c|c|c|c|c|c|}
\hline \multirow[b]{3}{*}{ Reduces electricity bill } & \multicolumn{2}{|c|}{$<1603 €$} & \multicolumn{2}{|c|}{$1603 €-2145 €$} & \multicolumn{2}{|c|}{$2452 €-3005 €$} & \multicolumn{3}{|c|}{$>3005 €$} \\
\hline & Avg & St Dev & Avg & St Dev & Avg & St Dev & Avg & St Dev & Sig. Anova \\
\hline & 7.4 & 2.5 & 7.6 & 2.4 & 7.9 & 2.2 & 7.8 & 2.2 & 0.00 \\
\hline Reduces gas bill & 7.3 & 2.4 & 7.5 & 2.4 & 7.8 & 2.2 & 7.8 & 2.1 & 0.00 \\
\hline Increases comfort & 7.4 & 2.2 & 7.5 & 2.2 & 7.7 & 2.1 & 7.6 & 2.1 & 0.00 \\
\hline Aids preserving temperature & 7.8 & 2.1 & 7.9 & 2.0 & 8.2 & 1.9 & 8.2 & 1.8 & 0.00 \\
\hline Is more expensive & 6.4 & 2.6 & 6.4 & 2.7 & 6.5 & 2.6 & 6.4 & 2.6 & 0.62 \\
\hline$n$ & 2,221 & & 1,021 & & 1,509 & & 514 & & \\
\hline
\end{tabular}

Sex

\begin{tabular}{cccrc}
\multicolumn{4}{c}{ Women } & \multicolumn{3}{c}{ Men } \\
\hline Avg & St Dev & Avg & St Dev & Sig. Anova \\
\hline 7.5 & 2.4 & 7.8 & 2 & 0.00 \\
\hline 7.4 & 2.4 & 7.6 & 2 & 0.00 \\
\hline & 2.1 & & 2 & 0.61 \\
\hline 7.9 & 2.0 & 8.1 & 2 & 0.00 \\
\hline 6.4 & 2.7 & 6.5 & 3 & 0.01 \\
\hline 3,040 & & 2,226 &
\end{tabular}

Current home tenure regime

\begin{tabular}{cccrc} 
Tenants & \multicolumn{3}{c}{ Owners } \\
\hline Avg & St Dev & Avg & St Dev & Sig. Anova \\
\hline & 2.4 & & 2.3 & 0.17 \\
\hline 7.4 & 2.4 & 7.6 & 2.3 & 0.01 \\
\hline 7.5 & 2.2 & 7.6 & 2.1 & 0.07 \\
\hline 7.9 & 2.1 & 8.0 & 1.9 & 0.15 \\
\hline 6.3 & 2.7 & 6.5 & 2.6 & 0.00 \\
\hline 2,231 & & 3,035 & &
\end{tabular}

The gradient color from soft yellow to dark green correspond to the numerical values gradient, from lower to higher ones.

Figure 5. Perceived co-benefits according to respondents' sociodemographic profile. Source: Self elaboration.

Finally, respondents that live in their own home express a larger agreement to most of the co-benefits, including the larger home value for efficient homes. This latter finding is consistent with the previously discussed results coming from market segmentation.

\subsection{Living Conditions as an Expression of Retrofit Requirements}

Respondents' current living conditions can be indirectly assessed when asking for the requirements to implement specific home retrofits regarding the three dimensions discussed in the methodological section, as well as, in the case of retrofit necessity, the relative priority to implement such improvements. To some extent, the current living conditions may exert a role in the perception of energy-performance co-benefits, especially in the case of people whose residential environment alternatively implies high energy consumption to reach a proper comfort level, or a poor comfort level to reach an affordable energy consumption. Past research, in Spain, has identified a relationship between poor/adequate energy-related living conditions and willingness to pay for energy-efficient homes [6]. 
In this paper we go a step further to learn whether such conditions do affect the perceived co-benefits of energy performance. As said before, $88 \%$ of respondents' homes do require to be improved in the assessed aspects. However, if such retrofits are split, relevant differences emerge: $90 \%$ of homes require a retrofit associated to passive energy-efficient actions (e.g., building envelope insulation), the figure is reduced to $86 \%$ in the case of active energy-efficient improvements (e.g., HVAC); while $88 \%$ of respondents require non-energy efficient improvements (e.g., kitchens) to be evaluated. Such findings are related with the fact that in the context of multifamily homes, which is dominant in Spain, implementing passive improvements is significantly more complex due to the communal nature of building envelope elements, comparing to improving private spaces such as bathrooms and kitchens or replacing individual boilers. For these reasons these latter retrofits are more popular than others effecting the energy performance. Thus, the gap of such passive-energy conditions is larger than those related to private elements.

Figure 6 illustrates the percentage of homes requiring a specific retrofit as well as the percentage who felt it necessary to prioritize implementation; the information is split according to respondents' sociodemographic profile. From this, the following conclusions can be highlighted:

\begin{tabular}{|c|c|c|c|c|c|}
\hline & \multicolumn{5}{|c|}{ Homes not requiring retrofits } \\
\hline & \multicolumn{5}{|l|}{ Age } \\
\hline & \multirow{2}{*}{$\frac{18-24}{\%}$} & \multirow{2}{*}{$\begin{array}{l}\text { 25-34 } \\
\%\end{array}$} & \multirow{2}{*}{$\begin{array}{l}35-54 \\
\%\end{array}$} & \multicolumn{2}{|c|}{55 and more } \\
\hline & & & & $\%$ & Sig. $\mathrm{Chi}^{\wedge} 2$ \\
\hline Kitchen & $7 \%$ & $9 \%$ & $13 \%$ & $15 \%$ & 0.00 \\
\hline Bath & $7 \%$ & $9 \%$ & $12 \%$ & $15 \%$ & 0.00 \\
\hline Layout improvement & $9 \%$ & $11 \%$ & $13 \%$ & $17 \%$ & 0.00 \\
\hline Wall insulation & $4 \%$ & $9 \%$ & $11 \%$ & $13 \%$ & 0.00 \\
\hline Window insulation & $4 \%$ & $8 \%$ & $10 \%$ & $14 \%$ & 0.00 \\
\hline Boiler EE improvement & $9 \%$ & $12 \%$ & $15 \%$ & $19 \%$ & 0.00 \\
\hline Install/improve EE AC & $9 \%$ & $11 \%$ & $14 \%$ & $16 \%$ & 0.00 \\
\hline Install/improve solar protection & $7 \%$ & $9 \%$ & $12 \%$ & $15 \%$ & 0.00 \\
\hline
\end{tabular}

\begin{tabular}{|c|c|c|c|c|c|c|c|c|c|}
\hline \multirow[b]{4}{*}{$\mathrm{n}$} & \multicolumn{9}{|c|}{ Average priority for retrofits } \\
\hline & \multicolumn{9}{|l|}{ Age } \\
\hline & \multicolumn{2}{|c|}{$18-24$} & \multicolumn{2}{|c|}{$25-34$} & \multicolumn{2}{|c|}{$35-54$} & \multicolumn{2}{|c|}{55 and more } & \\
\hline & Avg & St Dev & Avg & StDev & Avg & St Dev & Avg & St Dev & Sig. Anova \\
\hline 5,451 & 6.9 & 2.5 & 7.0 & 2.5 & 6.5 & 2.8 & 6.4 & 2.9 & 0.00 \\
\hline 5,485 & 6.7 & 2.5 & 6.8 & 2.6 & 6.3 & 2.8 & 6.2 & 3.0 & 0.00 \\
\hline 5,389 & 5.2 & 2.7 & 5.0 & 2.7 & 4.6 & 2.8 & 4.2 & 3.0 & 0.00 \\
\hline 5,566 & & 2.5 & & 2.5 & & 2.8 & & 3.1 & 0.23 \\
\hline 5,576 & 7.2 & 2.5 & 7.6 & 2.4 & 7.6 & 2.6 & 7.4 & 2.9 & 0.01 \\
\hline 5,312 & & 2.5 & & 2.6 & & 3.0 & & 3.2 & 0.30 \\
\hline 5,344 & 5.5 & 2.7 & 5.6 & 2.8 & 5.6 & 3.2 & 5.7 & 3.3 & 0.77 \\
\hline 5,466 & 5.4 & 2.8 & 5.5 & 2.6 & 5.5 & 2.9 & 5.5 & 3.0 & 0.82 \\
\hline
\end{tabular}

\begin{tabular}{|c|c|c|c|}
\hline & \multicolumn{3}{|l|}{ Sex } \\
\hline & Women & Men & \\
\hline & $\%$ & $\%$ & Sig. $\mathrm{Chi}^{\wedge} 2$ \\
\hline Kitchen & $13 \%$ & $9 \%$ & 0.00 \\
\hline Bath & $13 \%$ & $9 \%$ & 0.00 \\
\hline Layout improvement & $14 \%$ & $10 \%$ & 0.00 \\
\hline Wall insulation & $11 \%$ & $8 \%$ & 0.00 \\
\hline Window insulation & $11 \%$ & $8 \%$ & 0.00 \\
\hline Boiler EE improvement & $16 \%$ & $11 \%$ & 0.00 \\
\hline Install/improve EE AC & $15 \%$ & $11 \%$ & 0.00 \\
\hline Install/improve solar protection & $13 \%$ & $9 \%$ & 0.00 \\
\hline
\end{tabular}

\begin{tabular}{llllll}
\hline $\mathrm{n}=6,167$ & \multicolumn{5}{c}{ Household net monthly income } \\
& \multicolumn{3}{c}{$\mathbf{1 6 0 3 € -}$} & $\mathbf{2 4 5 2 € -}$ \\
& $<\mathbf{1 6 0 3 €}$ & $\mathbf{2 1 4 5 €}$ & $\mathbf{3 0 0 5 €}$ & $\mathbf{> 3 0 0 5 €}$ \\
\cline { 2 - 6 } & $\%$ & $\%$ & $\%$ & $\%$ & Sig. Chi \\
& $7 \%$ & $9 \%$ & $13 \%$ & $15 \%$ & 0.00 \\
\hline Kitchen & $7 \%$ & $9 \%$ & $12 \%$ & $15 \%$ & 0.00 \\
\hline Bath & $9 \%$ & $11 \%$ & $13 \%$ & $17 \%$ & 0.00 \\
\hline Layout improvement & $4 \%$ & $8 \%$ & $11 \%$ & $13 \%$ & 0.00 \\
\hline Wall insulation & $4 \%$ & $8 \%$ & $10 \%$ & $14 \%$ & 0.00 \\
\hline Window insulation & $9 \%$ & $12 \%$ & $15 \%$ & $19 \%$ & 0.00 \\
\hline Boiler EE improvement & $9 \%$ & $11 \%$ & $14 \%$ & $16 \%$ & 0.00 \\
\hline Install/improve EE AC & $7 \%$ & $9 \%$ & $12 \%$ & $15 \%$ & 0.00 \\
\hline Install/improve solar protection & $7 \%$ & & & &
\end{tabular}

\begin{tabular}{lccccr} 
& \multicolumn{3}{c}{ Sex } & Women & Men \\
\cline { 2 - 6 } $\mathrm{n}$ & Avg & St Dev & Avg & St Dev & Sig. Anova \\
\hline 5,451 & 6.8 & 2.8 & 6.4 & 2.6 & 0.00 \\
\hline 5,485 & 6.6 & 2.8 & 6.3 & 2.7 & 0.00 \\
\hline 5,389 & 4.8 & 2.9 & 4.7 & 2.7 & 0.20 \\
\hline 5,566 & 7.0 & 2.8 & 6.6 & 2.7 & 0.00 \\
\hline 5,576 & 7.6 & 2.6 & 7.4 & 2.6 & 0.00 \\
\hline 5,312 & 6.6 & 2.9 & 6.4 & 2.8 & 0.01 \\
\hline 5,344 & 5.5 & 3.1 & 5.7 & 2.9 & 0.06 \\
\hline 5,466 & 5.5 & 2.9 & 5.4 & 2.7 & 0.32 \\
\hline
\end{tabular}

\begin{tabular}{|c|c|c|c|c|c|c|c|c|c|}
\hline \multirow[b]{3}{*}{ ? } & \multicolumn{4}{|c|}{ Household net monthly income } & \multirow{2}{*}{\multicolumn{2}{|c|}{$\begin{array}{l}2452 €- \\
3005 €\end{array}$}} & \multirow{2}{*}{\multicolumn{2}{|c|}{$>3005 €$}} & \multirow[b]{3}{*}{ Sig. Anova } \\
\hline & $<1603$ & & $\begin{array}{l}1603 € \\
2145 €\end{array}$ & & & & & & \\
\hline & Avg & St Dev & Avg & St Dev & Avg & St Dev & Avg & StDev & \\
\hline 5,451 & & 2.7 & & 2.6 & & 2.7 & & 2.8 & 0.77 \\
\hline 5,485 & 6.7 & 2.6 & 6.4 & 2.7 & 6.3 & 2.8 & 6.5 & 2.8 & 0.04 \\
\hline 5,389 & 4.8 & 2.7 & 4.8 & 2.7 & 4.8 & 2.8 & 4.6 & 2.9 & 0.16 \\
\hline 5,566 & 6.6 & 2.7 & 6.8 & 2.6 & 6.8 & 2.7 & 6.9 & 2.8 & 0.04 \\
\hline 5,576 & 74 & 2.6 & 7.6 & 2.5 & 7.5 & 2.6 & 7.6 & 2.6 & 0.65 \\
\hline 5,312 & 5 & 2.8 & - & 2.7 & 5 & 2.9 & 5 & 3.0 & 0.49 \\
\hline 5,344 & 5.7 & 2.9 & 5.6 & 2.9 & 5.7 & 3.0 & 5.6 & 3.2 & 0.81 \\
\hline 5,466 & 5.5 & 27 & 5.6 & 27 & 5.5 & 29 & 5.5 & 29 & 0.74 \\
\hline
\end{tabular}

\section{Current home tenure regime}

\begin{tabular}{lrrr} 
& \multicolumn{4}{c}{ Tenants } & Owners & \\
\cline { 2 - 4 } & $\%$ & $\%$ & Sig. Chi^2 \\
\hline Kitchen & $9 \%$ & $14 \%$ & 0.00 \\
\hline Bath & $9 \%$ & $13 \%$ & 0.00 \\
\hline Layout improvement & $10 \%$ & $14 \%$ & 0.00 \\
\hline Wall insulation & $8 \%$ & $11 \%$ & 0.00 \\
\hline Window insulation & $7 \%$ & $12 \%$ & 0.00 \\
\hline Boiler EE improvement & $12 \%$ & $16 \%$ & 0.00 \\
\hline Install/improve EE AC & $11 \%$ & $15 \%$ & 0.00 \\
\hline Install/improve solar protection & $10 \%$ & $13 \%$ & 0.00 \\
\hline
\end{tabular}

\begin{tabular}{lccccc}
\multicolumn{7}{c}{ Current home tenure regime } \\
$\mathrm{n}$ & \multicolumn{2}{c}{ Tenants } & \multicolumn{3}{c}{ Owners } \\
\cline { 2 - 7 } & Avg & St Dev & Avg & St Dev & Sig. Anova \\
\hline 5,451 & 6.9 & 2.6 & 6.4 & 2.8 & 0.0 \\
\hline 5,485 & 6.7 & 2.7 & 6.2 & 2.8 & 0.0 \\
\hline 5,389 & 4.9 & 2.8 & 4.6 & 2.8 & 0.0 \\
\hline 5,566 & 7.1 & 2.7 & 6.6 & 2.7 & 0.0 \\
\hline 5,576 & 7.9 & 2.5 & 7.3 & 2.6 & 0.0 \\
\hline 5,312 & 6.7 & 2.8 & 6.4 & 2.9 & 0.0 \\
\hline 5,344 & 5.7 & 3.1 & 5.5 & 3.0 & 0.0 \\
\hline 5,466 & 5.5 & 2.8 & 5.5 & 2.8 & 0.6 \\
\hline
\end{tabular}

The gradient color from soft yellow to dark green correspond to the numerical values gradient, from lower to higher ones.

Figure 6. Retrofit requirements and priorities according to respondents' sociodemographic profile. Source: Self elaboration. 
Findings Regarding Respondents' Age

(1) In general, the older the respondents, the lower the requirement to implement specific retrofits in their current home. Such a finding suggests that living conditions improve as the residential carrier gains consolidation, although it also possibly masks some conformism regarding living conditions in the case of elder population. However, the requirement to improve envelope insulation (walls and windows) is largely irrespectively of the age of respondents.

(2) Looking at homes requiring improvements, non-energy efficiency improvements, such as kitchen, bathroom or layout improvements, are less of a priority as the age of respondents' increases. Interestingly, the exact inverse trend is observed in the case of window insulation which relevance becomes larger in the case of older respondents. Findings Regarding Respondents' Gender

(3) In general, women's homes require less improvements than male respondents' ones, thus female respondents exhibit better living conditions in relation to male respondents. Perhaps for this reason, women's co-benefits perception is lower in relation to males' one as discussed in the former section. Irrespectively of gender, the most required improvements concentrate on energy-efficiency passive actions, namely home envelope insulation.

(4) Looking at homes requiring improvements, in both genders, energy-efficient improvements are of a greater priority than aesthetic-functional-accessibility ones, although women do place a larger priority on this than men. However, women prioritize non-energy efficient improvements (bathroom, kitchen and layout) to a larger extent than men, showing a clear gender influence probably linked to the way in how home duties are split between women and men. It is worth nothing that men place more importance to retrofits associated with the air-conditioning system.

Findings Regarding Income Level

(5) As expected, the larger the income, the better the living conditions of respondents. As such, $93 \%$ of homes of households whose income is less than $€ 1603$ per month require retrofits; while homes of households making more than $€ 3005$ a month do require improvements in $85 \%$ of cases.

(6) Considering only homes requiring retrofits, the priority to implement them decreases as the household incomes increases in almost all of the aspects assessed. Interestingly, this trend is reversed in the case of insulation, especially in the case of wall insulation which prioritization is statistically larger in the case of wealthier households.

(7) Differences in living conditions among tenants and owners are compatible with the previously discussed transitory housing tenure. In general, tenants say their homes require retrofits to a larger extent than owners. Again, insulation issues are the most required in both regimes, although significantly more in the case of leased homes.

(8) Looking only at homes requiring improvements, again the priority to implement them is higher in the case of tenants. By priority order the stated improvements are as follows: Passive systems, active and non-energy-efficiency ones. However, the households who own their home state that window/wall insulation has a larger priority than improving the kitchen, bathroom or the home layout.

While the previous market and sociodemographic segmentations shed light on the relationship between perceived preferences and living conditions, it is necessary to assess such relations under a multivariate analysis so as to isolate the effect of each attribute and avoid the effect of uneven distributions among segmentation variables previously discussed. 


\subsection{Factors Influencing the Perception of Energy Efficiency Benefits}

Figure 7 illustrates the coefficients of the multiple regression analysis aimed at isolating the marginal contribution of sociodemographic and living conditions over the intensity in which respondents perceive the assessed co-benefits of energy efficiency. Such a model is specified only with the variables statistically significant at $95 \%$ confidence. One of these values is beta coefficient, which allows to compare the relative importance of the independent variables on the variation of the dependent variable. Such a procedure consists of regressing the dependent variables on the standardized scale of the independent variables. Typically, $z$-values procedure is used to standardize the variables getting as a result a distribution whose average value is zero and standard deviation is one. According to the beta coefficient, calibrated using the standardized variables, the following findings can be extracted:

(1) The main explanatory attribute is the priority to insulate respondents' present home windows. The higher such priority, the larger the composite co-benefits associated with energy efficiency. It is worth recalling that window transmittance is the largest among enveloping elements in multifamily housing where poor-quality windows imply airflow infiltrations and external noise transmission. In that, the benefits of upgrading this element are of a multidimensional nature, as discussed in Section 2.2.

(2) The second explanatory attribute concerns the socioeconomic context. The lower the respondent socioeconomic level, the less aware of the energy efficiency co-benefits. It is worth recalling the strong association in Spain between disposable family income and educational attainment, in that, well educated respondents do have better cognitive resources to understand the benefits of efficient premises even when they are not specialists.

(3) The third most important explanatory factor is the indirect indicator of willingness to pay for efficient homes. In turn, respondents that think that efficient homes pursue a higher market value are also the most aware of energy efficiency implications. This finding is relevant since it empirically endorses the core hypothesis of the EPC scheme, regarding the relationship between energy transparency and prioritization of efficient premises in the form of a larger willingness to pay for them.

(4) The fourth explanatory element is related to the priority to implement energy-efficient retrofits in heating/domestic hot water and air-conditioning systems. Respondents who consider this a priority in their current home are more aware of the composite benefits of energy efficiency.

(5) Regarding demographic profiles, after having controlled for income, women are less aware of energy efficiency benefits as well as young respondents. These findings are a clear target for tailoring specific policies aimed at increasing energy performance awareness. The same is true regarding the role within the residential market, since the findings confirm that owners do place a large value on the benefits of energy efficiency in relation to tenants. It is worth recalling that women said in a larger proportion that their home does not require the assessed retrofits (i.e., their homes exhibit better living conditions in relation to male respondents' home), so as suggested before, it is possible that this fact has influenced their response; although it is also possible that female respondents have a more optimistic perception of their homes in relation to male respondents. In the model, interaction variables between gender and living conditions were introduced, but none resulted statistically significant.

(6) The positive relation between energy efficiency benefits awareness and the fact that respondents' homes do not require the installation or improvement of air conditioners should be interpreted as an indirect indicator of climate conditions, since according to correlational analysis respondents indicating that their home do not require such appliance live in cooler regions where the energy demand for heating is relevant in winter. 


\begin{tabular}{cccccc}
\hline & & & & \multicolumn{2}{c}{ ANOVA } \\
\cline { 3 - 6 } & $\mathrm{R}$ & sq R & Adjusted R & Sig. \\
\hline 0.368 & 0.135 & 0.133 & Freedom degrees & 2,712 \\
\hline
\end{tabular}

\begin{tabular}{|c|c|c|c|c|c|c|c|}
\hline \multirow[b]{2}{*}{ Indpendent variables } & \multirow[b]{2}{*}{ B } & \multirow[b]{2}{*}{ Std Error } & \multirow[b]{2}{*}{ Beta } & \multirow[b]{2}{*}{$\mathrm{t}$} & \multicolumn{3}{|c|}{ Collinearity statistics } \\
\hline & & & & & Sig & Tolerance & VIF \\
\hline Constant & 1.190 & 0.036 & & 33.07 & 0.000 & & \\
\hline Ln_window insulation priority & 0.144 & 0.010 & 0.285 & 14.51 & 0.000 & 0.827 & 1.209 \\
\hline Socioeconomic ladder & -0.009 & 0.002 & -0.101 & -5.58 & 0.000 & 0.969 & 1.033 \\
\hline Indirect willigness to pay indicator & 0.004 & 0.001 & 0.078 & 4.34 & 0.000 & 0.995 & 1.005 \\
\hline Ln_age & 0.027 & 0.008 & 0.064 & 3.41 & 0.001 & 0.910 & 1.099 \\
\hline Retrofit energy efficiency active systems & 0.002 & 0.001 & 0.075 & 3.73 & 0.000 & 0.790 & 1.266 \\
\hline Woman & -0.013 & 0.005 & -0.054 & -2.89 & 0.004 & 0.927 & 1.079 \\
\hline Buyer & 0.010 & 0.004 & 0.039 & 2.19 & 0.029 & 0.991 & 1.009 \\
\hline required & 0.032 & 0.015 & 0.038 & 2.05 & 0.041 & 0.934 & 1.070 \\
\hline
\end{tabular}

Notes: controlled for fixed effects a regional scale, stepwise procedure

A number of interactions variables has been tested, non of them has proved a significat correlation with LnCB Dependent variable: $\mathrm{LnCB}$

The blue and red bars are a graphical representation of the percentage values.

Figure 7. Regression model to identify the factors influencing the perception of EE benefits. Source: Self elaboration.

Finally, the relatively low fit of the model suggests that the awareness of energy performance benefits may be also explained by other aspects not inquired within the survey. Among others, it is important to note the possible existence of environmental conservation, despite that some studies have found it to have a small role in retrofit motivation [44]; ethical aspects or the existence of other co-benefits such as health improvement as pointed out by Calvo-Torras et al. [26] which existence requires further research.

\section{Conclusions}

In Spain despite the generalization of EPCs in 2013, in transposition of the EPBD (2010/31/UE), there is no clear evidence on the diffusion of efficient homes nor retrofit of existing ones. Existing research reviewed in Section 2.3 in this paper offers inconclusive evidence on the effectiveness of such an EU policy. Drawing on statistical analysis of prices, small, uneven and even non-existent correlations among home prices and EPC ratings have been found. Viewing surveys and interviews given to real estate agents and property experts a number of issues arising from the EPC scheme have been pointed out. As a consequence, such a scheme is seen as ineffective in fostering end users to engage with efficient premises. In turn, designers, builders, developers and other agents in the housing industry do not place a special interest in delivering homes with an energy benchmark surpassing the minimum required by construction codes. Not surprisingly, EP certified " $\mathrm{A}$ " or " $\mathrm{B}$ " buildings only account for $1.1 \%$ of all EPCs.

Whether such lack of interest on efficient premises comes from a lack of perceived co-benefits requires further exploration. This paper sheds lights on such understanding by surveying a large sample of households that have recently participated as buyers, sellers, tenants and landlords in the Spanish housing market. Namely, the interest of the research is placed in: (1) learning whether such agents do perceive selected co-benefits of efficient homes in the form of energy savings and comfort; (2) whether such perception is influenced by respondents' current living conditions; and (3) whether it is influenced by their sociodemographic features including the housing tenure and the role they have played within the real estate market. 
Results suggest that the assessed energy performance co-benefits seem to be well established among respondents. Interestingly, such perception is stronger in the case of thermal comfort than energy savings. This finding is quite relevant since in Spain the prescription of efficient premises has been only based on signaling the potential energy savings and $\mathrm{CO}_{2}$ emissions, putting aside any other co-benefit. In turn there is room for energy policy improvement by signaling comfort and other benefits identified by past research. The second finding is that efficient homes are not perceived as deserving a larger market value. Such a conclusion is in line with historic research in the country that has found, as previously stated, a small or even null correlation between EPC ratings and prices.

When the perception of the assessed co-benefits is analyzed in detail to learn differences among respondents, relevant specificities emerge. It seems that elder, wealthier, homeowner and male respondents perceive to a greater extent the energy performance co-benefits. Interestingly, the relation seems to be far from linear: There is a larger gap between low-income and medium-income households in relation to medium and highincome ones, which suggest that educational attainment may play a role in understanding the relationship between efficiency, energy savings and comfort. Interestingly, landlords, irrespectively of if they play a role as buyers, sellers or lessors, do place a large relevance to co-benefits. This finding also challenges public policy in a country where $72 \%$ of homes are owner-occupied at the time that housing policies foster tenancy as an affordable housing tenure.

The perception of co-benefits, beyond personal attitudes, should be influenced by respondents' close built environment in the form of living conditions as hypothesized in this paper. Such living conditions can be assessed by learning about the household's current home retrofit requirements and priorities to carry out such retrofits. According to our results, the living conditions in Spanish homes are worrying since most of the respondents pointed out the necessity to implement a retrofit urgently. This conclusion is especially true in the case of insulation of walls and windows, which are the main elements of buildings envelope. This finding is wholly related to the fact that most of dwellings in the country are placed in multifamily properties which improvement of communal areas (e.g., roofs and façades) do require the consensus of a majority of owners which, in addition to financial barriers, makes it improbable to improve buildings' skin.

Evidently, living conditions are far from homogeneous across socio demographic segments and housing tenure. The relationship between perceived benefits and living and sociodemographic conditions has been explored using a multiple regression approach. The results strongly indicate that poor living conditions in the form of poor envelope insulation is the main aspect influencing the perception of co-benefits. The poorer on this specific living condition, the larger the perceived financial and comfort co-benefits. The same is true, but to a lesser extent, regarding the poor living conditions associated with active conditioning systems. The following correlated attribute is the income (associated to educational attainment), the lower such attribute the lower the perceived co-benefits. Plus, respondents that think that efficient homes deserve a larger market price are also more conscious of the co-benefits. Finally, in our sample women seem to be less conscious of the financial and comfort co-benefits which may be explained by the fact that they live in better conditions (i.e., their homes require less retrofits in relation to male respondents' ones). Such gender conclusions may be different in the case of other co-benefits such as environment conservation or health preservation if they were included in the survey (which constitutes the main shortcoming of the present study to be further researched).

These findings strongly suggest that the diffusion of efficient premises do require socio-demographic tailored awareness campaigns; especially because it is necessary to expand such awareness not only among young generations, but also to home decision makers, if the 2030 EU goals (reduction of GHG in 40\%, increase of renewable energy in $32 \%$ and improvement of energy performance in $32.5 \%$ ) are going to be met. In that, EPC labels, as suggested by past research in Spain, do not accomplish the challenge to 
communicate in comprehensive units the repercussion of energy performance, nor do they include other relevant co-benefits such as comfort (assessed in this paper) or health perception (assessed in other studies reviewed in Section 2.2). Improving such labels is an imperative step towards the decarbonization of the property market.

The co-benefits in the form of comfort, energy savings and health will also gain relevance for conjunctural and climatic reasons. On the one hand, the COVID-19 lockdown in Spain, one of the strictest in the world, has highlighted the deficiencies of the residential interior environment at the time that accelerated the transition towards home tele-work. As a consequence, it is highly probably from now on, people will expend more time in homes, emphasizing issues regarding comfort, energy consumption and associated GHG emissions.

Collectively, such transition and macroeconomic co-benefits form a strong relevance in the communication of private and non-private co-benefits as a launch pad for effective energy-performance companion policies, especially those intended to blur the remainder of barriers for property decarbonization (discussed in Section 2.1). While the quantification of such benefits is not a straightforward process, it is possible to implement, as discussed in 2.2 , and can be a seed to foster top-tier efficient homes.

Author Contributions: Formal analysis, E.C.S., S.S.B., B.O.P. and C.M.-D.; Investigation, E.C.S., S.S.B., B.O.P. and C.M.-D.; Methodology, E.C.S., S.S.B., B.O.P. and C.M.-D.; Resources, E.C.S., S.S.B., B.O.P. and C.M.-D.; Writing-review \& editing, E.C.S., S.S.B., B.O.P. and C.M.-D. All authors have read and agreed to the published version of the manuscript.

Funding: This paper has been produced in the framework of the EnerValor2 (PID2019-104561RB-100).

Data Availability Statement: Public data used in this paper can be found at https://www.ine.es/.

Acknowledgments: The authors appreciate so much the detailed contributions and criticism of reviewers as well as the collaboration of Fotocasa Research in providing the adequate framework for the implementation of the survey. Also thank to Chen Ai and Rolando Biere for their support in assembling datasets.

Conflicts of Interest: The authors declare no conflict of interest.

\section{References}

1. Balaras, C.A.; Gaglia, A.G.; Georgopoulou, E.; Mirasgedis, S.; Sarafidis, Y.; Lalas, D.P. European residential buildings and empirical assessment of the Hellenic building stock, energy consumption, emissions and potential energy savings. Build. Environ. 2007, 42, 1298-1314. [CrossRef]

2. Jacques-Aviñó, C.; Dvorzak, J.L.; Marí-Dell'Olmo, M.; Arjona, D.R.; Peralta, A.; Carrere, J.; Benach, J.; Ramos, C.; Plana, M.; López, M.J. Qualitative evaluation of an intervention to reduce energy poverty. Rev. Saúde Pública 2019, 53, 62. [CrossRef]

3. Bio Intelligence Service; Lyons, R. IEEP Energy Performance Certificates in Buildings and Their Impact on Transaction Prices and Rents in Selected EU Countries; European Commission (DG Energy): Paris, France, 2013; p. 158.

4. Marmolejo-Duarte, C.; Chen, A. The Uneven Price Impact of Energy Efficiency Ratings on Housing Segments and Implications for Public Policy and Private Markets. Sustainability 2019, 11, 372. [CrossRef]

5. Marmolejo Duarte, C.; Garcia-Hoohghuis, A.; Garcia-Masia, A. How Much Does the Energy Class of Our Dwellings Matter to Us? An analysis of The Level of Understanding of EPCs, Willingness to Pay and Reasons for Payment in Barcelona. Rev. Habitat Sustentable 2017, 7, 55-65.

6. Marmolejo-Duarte, C.; Garcia-Hooghuis, A.; Garcia Masia, A. How much and why are we willing to pay for energy-efficient homes? A stated preferences analysis in Barcelona. ACE-Archit. City Environ. 2020, 14, 9215. [CrossRef]

7. Ortiz, J.; Fonseca i Casas, A.; Salom, J.; Garrido Soriano, N.; Fonseca i Casas, P. Cost-effective analysis for selecting energy efficiency measures for refurbishment of residential buildings in Catalonia. Energy Build. 2016, 128, 442-457. [CrossRef]

8. Marmolejo-Duarte, C.; Spairani-Berrio, S.; Del Moral-Ávila, C.; Delgado-Méndez, L. The Relevance of EPC Labels in the Spanish Residential Market: The Perspective of Real Estate Agents. Buildings 2020, 10, 27. [CrossRef]

9. Pascual, R.P.; Paoletti, G.; Lollini, R. Impact and reliability of EPCs in the real estate market. Energy Procedia 2017, 140, 102-114. [CrossRef]

10. Cañete, M.A. La eficiencia energética supone una oportunidad de 85,000 millones de euros en España. Revista Ecoconstrucción, 28 August 2019.

11. Trebilcock, M. Percepción de barreras a la incorporación de criterios de eficiencia energética en las edificaciones. Rev. Constr. 2011, 10, 4-14. [CrossRef] 
12. Lambea Rueda, A.; Ruiz, M.; Pastor, G. La sostenibilidad de la vivienda: Razones para incentivar su desarrollo en España. Revesco 2020, 133. [CrossRef]

13. García de Diego, M.D.L.; Gómez Muñoz, G.; Román López, E. Cuentas energéticas no habituales en edificación residencialTowards new energy accounting in residential building. Inf. Constr. 2015, 67, m028. [CrossRef]

14. Jevons, W.S. The Coal Question; An Inquiry Concerning the Progress of the Nation, and the Probable Exhaustion of our Coal-Mines. Fortnightly 1866, 6, 505-507.

15. Ferreira, M.; Almeida, M.; Rodrigues, A. Impact of co-benefits on the assessment of energy related building renovation with a nearly-zero energy target. Energy Build. 2017, 152, 587-601. [CrossRef]

16. Fuerst, F.; Oikarinen, E.; Harjunen, O. Green signalling effects in the market for energy-efficient residential buildings. Appl. Energy 2016, 180, 560-571. [CrossRef]

17. Dempsey, N.; Bramley, G.; Power, S.; Brown, C. The social dimension of sustainable development: Defining urban social sustainability. Sustain. Dev. 2011, 19, 289-300. [CrossRef]

18. Ürge-Vorsatz, D.; Herrero, S.T.; Dubash, N.K.; Lecocq, F. Measuring the Co-Benefits of Climate Change Mitigation. Annu. Rev. Environ. Resour. 2014, 39, 549-582. [CrossRef]

19. Clinch, J.P.; Healy, J. Cost-benefit analysis of domestic energy efficiency. Energy Policy 2000, 29, 113-124. [CrossRef]

20. Chapman, R.; Howden-Chapman, P.; Viggers, H.; O’Dea, D.; Kennedy, M. Retrofitting houses with insulation: A cost-benefit analysis of a randomised community trial. J. Epidemiol. Community Health 2009, 63, 271-277. [CrossRef]

21. Tirado Herrero, S.; Ürge-Vorsatz, D.; Petrichenko, K. Fuel Poverty Alleviation as a Co-Benefit of Climate Investments: Evidence from Hungary. In Proceedings of the European Council for an Energy-Efficient Economy, Belambra/Presqu'ile de Giens, France, 3-8 June 2013; Available online: https:/ / www.researchgate.net/publication/262048685_Fuel_poverty_alleviation_as_a_cobenefit_of_climate_investments_evidence_from_Hungary (accessed on 10 December 2020).

22. Ugarte, S.; van der Ree, B.; Voogt, M.; Eichhammer, W.; Ordoñez, J.A.; Reuter, M.; Schlomann, B.; Lloret Gallego, P.; Villafafila Robles, R. Energy Efficiency for Low-Income Households; Industry, Research and Energy Committee (ITRE): Brussels, Belgium, 2016 ; p. 104.

23. Gilbertson, J.; Grimsley, M.; Green, G. Psychosocial routes from housing investment to health: Evidence from England's home energy efficiency scheme. Energy Policy 2012, 49, 122-133. [CrossRef]

24. Howden-Chapman, P.; Viggers, H.; Chapman, R.; O'Sullivan, K.; Telfar Barnard, L.; Lloyd, B. Tackling cold housing and fuel poverty in New Zealand: A review of policies, research, and health impacts. Energy Policy 2012, 49, 134-142. [CrossRef]

25. Grün, G.; Urlaub, S. Towards an Identification of European Indoor en-Vironments' Impact on Health and Performance; Fraunhofer-Institut für Bauphysik IBP: Stuttgart, Germany, 2016; p. 10.

26. Calvo-Torras, M.A.; Casquero-Modrego, N.; Sellares, J.; Hernández-González, F.; Arosemena, E.L. The Role of Apartment Layout in the Incidence of Indoor Microorganisms and How They May Affect Occupants with an Interstitial Lung Disease. In Proceedings of the 16th International Conference on Indoor Air Quality and Climate (INDOOR AIR 2020), Seoul, Korea, 2-6 November 2020.

27. Lavelle, M.J.; Fahy, F. Consensus Lifestyle Survey-Report on Public Attitudes and Behaviours towards Sustainable Consumption and Sustainable Lifestyles in Ireland: (1) Methodology and Profiling; National University of Ireland Galway: Galway, Ireland, 2012.

28. Barón Rodríguez, A.; Ortíz Roncallo, M.; Larrea Eguiguren, A.; Ampudia Farías, A.; Marmolejo Duarte, C.R.; Garcia-Almirall, M.P. Study of the perception of thermal comfort, Residetial Satisfaction and management model, of the residents of the conservation and energy Rehabilitation Area in The Poroneos Street, Santa Coloma de Gramenet, Spain. In Proceedings of the International Congress Virtual City and Territory (XII CTV)—Intelligent Cities and Territories (CTV 2018), Mendoza, Argentina, 5-7 September 2018; CPSV: Barcelona, Spain; pp. 303-318.

29. Ahrentzen, S.; Erickson, J.; Fonseca, E. Thermal and health outcomes of energy efficiency retrofits of homes of older adults. Indoor Air 2016, 26, 582-593. [CrossRef] [PubMed]

30. Stephenson, J.; Barton, B.; Carrington, G.; Gnoth, D.; Lawson, R.; Thorsnes, P. Energy cultures: A framework for understanding energy behaviours. Energy Policy 2010, 38, 6120-6129. [CrossRef]

31. Pelenur, M. Household energy use: A study investigating viewpoints towards energy efficiency technologies and behaviour. Energy Effic. 2018, 11, 1825-1846. [CrossRef]

32. Duarte, C.M. La incidencia de la calificación energética sobre los valores residenciales: Un análisis para el mercado plurifamiliar en Barcelona. Informes Construcción 2016, 68, 156. [CrossRef]

33. Marmolejo-Duarte, C.; Chen, A. La incidencia de las etiquetas energéticas EPC en el mercado plurifamiliar español: Un análisis para Barcelona, Valencia y Alicante. Ciudad Y Territorio Estudios Territoriales (CyTET) 2019, 51, 101-118.

34. Taltavull de La Paz, P.; Perez-Sanchez, V.; Mora-Garcia, R.-T.; Perez-Sanchez, J.-C. Green Premium Evidence from Climatic Areas: A Case in Southern Europe, Alicante (Spain). Sustainability 2019, 11, 686. [CrossRef]

35. Cespedes-Lopez, M.-F.; Mora-Garcia, R.-T.; Perez-Sanchez, V.R.; Marti-Ciriquian, P. The Influence of Energy Certification on Housing Sales Prices in the Province of Alicante (Spain). Appl. Sci. 2020, 10, 7129. [CrossRef]

36. Marmolejo-Duarte, C.; García-Hooghuis, A.; Spairani-Berrio, S. Panorama de la certificación energética en España. La perspectiva de los principales agentes del engranaje inmobiliario residencial. Ciudad Y Territorio Estudios Territoriales (CyTET) 2020, LII, 437-454. [CrossRef]

37. Cadman, D. The Vicious Circle of Blame; The RICS Research Foundation: London, UK, 2000. 
38. Feijó-Muñoz, J.; Pardal, C.; Echarri, V.; Fernández-Agüera, J.; Assiego de Larriva, R.; Montesdeoca Calderín, M.; Poza-Casado, I.; Padilla-Marcos, M.Á.; Meiss, A. Energy impact of the air infiltration in residential buildings in the Mediterranean area of Spain and the Canary islands. Energy Build. 2019, 188-189, 226-238. [CrossRef]

39. Marmolejo Duarte, C.; González Tamez, C. Does noise have a stationary impact on residential values? J. Eur. Real Estate Res. 2009, 2, 259-279. [CrossRef]

40. Werner, S. The European Heat Market; Final Report; Ecoheatcool Work Package 1; Euroheat \& Power: Brussels, Belgium, 2006 ; pp. 31-33.

41. Pär Dalin, P.; Nilsson, J.; Rubenhag, A. The European Cold Market; Final Report; Ecoheatcool Work Package 2; Euroheat \& Power: Brussels, Belgium, 2006; pp. 10-12.

42. Ortiz, J.; Casquero-Modrego, N.; Salom, J. Health and related economic effects of residential energy retrofitting in Spain. Energy Policy 2019, 130, 375-388. [CrossRef]

43. Ayuntamiento de Santa Coloma de Gramenet. Área de Conservación y Rehabilitacion de la Calle Pirineos; Ayuntamiento de Santa Coloma de Gramenet, Área de Urbanismo, Servicios Municipales, Espacio Público, Civismo y Sostenibilidad: Santa Coloma de Gramenet, Spain, 2014.

44. Rau, H.; Moran, P.; Manton, R.; Goggins, J. Changing energy cultures? Household energy use before and after a building energy efficiency retrofit. Sustain. Cities Soc. 2020, 54, 101983. [CrossRef] 